\title{
Overlapping Political Budget Cycles
}

\author{
Dirk Foremny* Ronny Freier $^{\dagger}$ Marc-Daniel Moessinger ${ }^{\ddagger}$ Mustafa Yeter ${ }^{\S}$
}

June 24, 2018

\begin{abstract}
We advance the literature on political budget cycles by testing for cycles in expenditures for elections in the legislative and the executive branch. Using municipal data, we identify cycles independently for the two branches, evaluate the effects of overlaps, and account for general year effects. We find sizable effects on expenditures before legislative elections and even larger effects before joint elections. In the case of overlapping elections, we show that it is important whether the executive incumbent seeks re-election. To account for the potential endogeneity of that decision, we apply an IV approach based on age and pension eligibility rules.
\end{abstract}

Keywords: election cycles, municipal expenditures, legislative and executive elections, instrumental variables approach

JEL Classification Numbers: H11, H71, H72, H74

Acknowledgments: We thank Florian Ade, Jeanne Diesteldorf, Lars P. Feld, Peter Haan, Niklas Potrafke, Friedrich Schneider, Robert Schwager, Johannes Voget and seminar participants at the IIPF, ECPS, ZEW Public Finance Conference and the University of Göttingen for helpful comments and suggestions. We are greatly indebted to Fabian Franke, Jenny Freier, Kathrin Friedrich, Heike Hauswald, Ilknur Köysüren, Larissa Lehn and Marc Schmidt who provided excellent research assistance as well as Adam Lederer for editorial support. Ronny Freier (project: 10.12.2.092) as well as Marc-Daniel Moessinger and Mustafa Yeter (project: 10.12.1.094) gratefully acknowledge financial support from the Fritz Thyssen foundation. Dirk Foremny gratefully acknowledges financial support from the projects ECO2012-37131 (Ministerio de Educacíon y Ciencia) and 2014SGR420 (Generalitat de Catalunya). The usual disclaimer applies. The

* Institut d'Economia de Barcelona (I.E.B.) and University of Barcelona

$\dagger$ Technical University of Applied Sciences Wildau and German Institute for Economic Research (DIW Berlin)

$\ddagger$ Centre for European Economic Research (ZEW Mannheim)

$\S$ German Council of Economic Experts, Corresponding author: German Council of Economic Experts, c/o Federal Statistical Office, Gustav-Stresemann-Ring 11, 65189 Wiesbaden, E-Mail: mustafa.yeter@svrwirtschaft.de, Tel.: 0049-611-75-2764. 
authors declare that they do not have relevant or material financial interests that relate to the research in this paper. 


\section{Introduction}

Originating with Nordhaus (1975), a main paradigm of the political economics literature is that political agents act rationally when deliberately manipulating the economy or particular fiscal aggregates to gain an electoral advantage. Further theory (e.g., Rogoff and Sibert, 1988 and Rogoff, 1990) confirms the main prediction of that paradigm, even under rational expectations of voters. ${ }^{1}$ While the early empirical literature looks for cycles in macroeconomic aggregates, such as unemployment and inflation ${ }^{2}$, newer work highlights credible evidence for political budget cycles (henceforth, PBCs) in fiscal aggregates, such as debt, public expenditures and their composition (see Keech and Pak, 1989, Alesina et al., 1997, and Brender and Drazen, 2005). ${ }^{3}$ Overall, the PBC phenomenon is relatively well understood and the empirical evidence highlights its relevance in actual policy making (see Philips, 2016 and Dubois, 2016).

This paper contributes to this literature in two ways. First, we explore PBCs in overall public expenditures for regional elections in the legislative and the executive branch. ${ }^{4}$ We study the cycles of the two institutions independently, evaluate the effects of randomly occurring electoral overlaps, and separate the effects from general year effects. This contrasts with the existing literature, which focuses either on the legislative branch or on joint elections. ${ }^{5}$ Second, for the analysis of PBCs in the executive, we highlight the concerns related to the endogenous decision of incumbent executives to seek re-election. Overcoming that endogeneity is crucial, as we only expect PBCs when the incumbent competes for re-election. To that end, we use an instrumental variables approach based on the age of the incumbent as well as on public pension eligibility rules to achieve credible identification.

The testing ground for our analysis is at the German sub-national level. We focus on municipalities in the states of Bavaria and Baden-Württemberg because those two states share a comparable institutional design (in contrast to some other German states), and exploiting their particular features allow us causally to identify PBCs for the legislative and the executive branches, the effects of overlapping elections, all while accounting for year effects. For the 1992-2006 period, we observe all key variables on expenditures, transfers,

1 Alternatively, Persson and Tabellini (2000) and Shi and Svensson (2006) provide a theoretical foundation for political budget cycles under rational expectations and moral hazard. A second strand of theoretical work relates to partisan cycles (e.g., Hibbs, 1977; Alesina, 1987, 1988a) that explain electoral cycles by shifts in political ideology.

2 Studies finding only weak or no evidence for cycles in real macroeconomic aggregates include, among others, Lächler (1978), Golden and Poterba (1980) and Alesina et al. (1997).

3 Further evidence at the national level is provided by Alesina (1988b), Alesina et al. (1992), Schuknecht (1999), Potrafke (2012), and Klomp and De Haan (2013).

4 While some papers study the composition of spending and distinguish between different types of spending categories that are more or less observable (see, e.g., Khemani (2004); Drazen and Eslava (2010)), we take the route of most of the literature and study total expenditures.

5 The unique setting of our design is acknowledged in Alesina and Passalacqua (2016) in the Handbook of Macroeconomics. 
elections to the legislative and the executive branch, as well as important socio-economic characteristics (population, age structure, ideological indicators for councils and mayors). ${ }^{6}$

Our paper is related to a broader literature focusing on PBCs in (local or regional) expenditures. In Table A.1 in the appendix, we provide a detailed and exhaustive overview of papers studying such cycles at the sub-national level. In total, we document 30 studies with evidence from 16 countries. ${ }^{7}$ Most research focuses on legislative elections and uses variation over time to separate election effects from general year effects. ${ }^{8}$

Apart from the papers in Table A.1, we identify four additional relevant studies. Using alternative outcome variables and focusing on local elections in Germany, Foremny and Riedel (2014) (taxes) and Englmaier and Stowasser (2013) (savings bank lending) provide evidence that PBCs are important. ${ }^{9}$ In addition, Furdas et al. (2015) present a closely related analysis in which interactions of PBCs in expenditures across different German governmental tiers (local legislative elections and corresponding state elections) are the focus of attention. ${ }^{10}$ The work by Hessami (2018) highlights the differences stemming from a further dimension of election laws. Only mayors that are elected directly by the voters (and not appointed by the council) are shown to have an incentive to attract more state investment grants in election years.

For elections to the executive branch, only a limited number of papers investigate PBCs (e.g., Rose, 2006; Alt and Rose, 2009; Garmann, 2017b). One reason is that the executive frequently is not elected directly by the voters (Hessami (2018) being a notable exception). In addition, even if separate elections are held, the timing of those elections often coincide. The papers by Rosenberg (1992) for Israel and Aidt et al. (2011) for Portugal both study cases in which legislative and executive branch elections are held simultaneously. In both studies, the authors control directly for whether the incumbent executive seeks re-election,

6 While a longer time series would always be desirable, we are bound by data availability in BW before 1992 and the introduction of new accounting standards in BAY after 2006.

7 More broadly, our paper generally contributes to the understanding of political economy at the regional level (see, e.g., Kessing (2010); Solé-Ollé and Viladecans-Marsal (2013); Baskaran (2012); Freier and Odendahl (2015); Garmann (2015)).

8 Note that the literature is divided into those studying the size of aggregate expenditures close to elections (similar to our question) and those testing for PBCs in the composition of expenditures. Evidence for the latter is first presented by Blais and Nadeau (1992) and Kneebone and Mckenzie (2001) for Canada and subsequently by Drazen and Eslava (2010), Veiga and Veiga (2007) and Akhmedov and Zhuravskaya (2004) in the case of municipal or regional legislative elections in Colombia, Portugal, and Russia, respectively. Common to all their results is a shift in expenditures, especially to categories with high visibility for the electorate.

9 Earlier studies for Germany include Seitz (2000), Galli and Rossi (2002), Schneider (2010) as well as Mechtel and Potrafke (2013), which test for PBCs in total expenditures, budget deficits and unemployment using state-level data.

10 In section 5, we highlight that we can control for the timing of state-level elections. However, as we have just two states, we cannot make the same analytical progress (carefully studying the interaction of those cycles) as skillfully achieved by Furdas et al. (2015). On the other hand, our focus on executive and legislative cycles can be studied uniquely in the present design, as institutional circumstances and data availability prevent us from using other German states. 
but cannot treat the endogeneity of that decision. Our contribution is that we tackle such endogeneity using a novel instrumental variables approach.

Crucial for the validity of our empirical analysis is the fact that local election dates are regulated by state law and are, therefore, set exogenously with very little or virtually no influence on the timing in individual municipalities. The legislative elections throughout our sample are held on state-specific dates. In contrast, regulations with respect to executive elections differ between states, i.e., election dates for the executive branch sometimes align with council elections and sometimes held on municipal-specific dates that differ from the dates of legislative elections (see Section 5). Given this differing structure of election timing, we can identify PBCs in both legislative and executive branch elections plus separate those effects from general year effects.

Our main results are threefold. First, we identify sizable and significant increases in total expenditures in pre-election years for the legislative branch. These results are in the range of 1.3-1.8 percent of total expenditures and remain stable throughout all of our robustness tests. For a medium-sized town of 5,000 inhabitants, this amounts to additional spending in the order of about 170,000 Euro in the year prior to the election. Second, we find that the cycles induced by legislative elections are unaffected by the timing of executive branch elections. Third, we show a significant effect of overlapping cycles conditional on the incumbent's decision to seek re-election. Aggregate expenditures increase in joint preelection and election years if the incumbent executive seeks re-election and decline in joint post-election years if she did not. For instance, given that the incumbent reenters the race for office, local spending in overlapping pre-election years is 5.5 percent larger than in the counterfactual situation when the incumbent does not seek re-election. However, our results come with one caveat: The complex structure of our estimations with several interaction terms saturates the model such that, given the number of observations, some results are only marginally significant.

The paper is organised as follows. Section 2 discusses the institutional setting while Section 3 derives hypotheses. Section 4 presents our data and descriptive statistics. In Section 5 we lay out the identification strategy, Section 6 discusses the main results and Section 7 presents the sensitivity analyses. Section 8 concludes.

\section{Institutional background}

The institutional arrangements of Baden-Württemberg (BW) and Bavaria (BAY) equip us with the exact features we need in order to test the hypothesis of overlapping PBCs. ${ }^{11}$ Municipalities are governed by an elected council and a directly elected mayor. Councils act

11 The municipal level in Germany is the lowest of four governmental tiers. In addition to the federal level, Germany comprises 16 federal states, about 450 counties, and about 12,000 municipalities. 
as the legislative body and mayors represent the executive branch. ${ }^{12}$ While the legislative members are elected based on open list proportional elections, majoritarian elections are held to determine the race for the executive branch. ${ }^{13}$ In BAY, the legislative and executive branch are elected for six years on (generally) the same statewide election day. ${ }^{14}$ In contrast, election terms in BW are of different length and election days vary accordingly: the local head of the executive branch is elected for eight years, while legislative elections are held every five years. Furthermore, only legislative elections are held on the same statewide day. The election dates for the executive branch are municipal-specific, i.e., each municipality has its own electoral cycle for such elections.

We illustrate the distribution over time of both types of elections in our estimation sample in Figure $1 .{ }^{15}$ Within the time horizon of this study, we observe legislative elections held in 1996 and 2002 in BAY and in 1994, 1999, and 2004 in case of BW. Executive elections in BW spread evenly throughout the years and only randomly overlap with legislative elections (14.7\% of the cases). In BAY, both elections generally run parallel. As an exception to the general rule, $10.7 \%$ of the executive election cycles in our estimation sample deviate (as some past election cycles ended prematurely). We examined the deviating towns carefully and find them to be significantly larger in size and to differ in their demographic compositions. To make sure that our results are not driven by the few deviating observations in BAY, we also repeat the analysis dropping those non-standard observations. Reassuringly, the results remain comparable to our main findings.

Crucial for the validity of our empirical analysis is the fact that the timing of local elections (legislative as well as executive) is regulated by state law and is, for the most part, beyond the control of individual municipalities. The timing of the legislative elections is fixed entirely by given state wide election terms and therefore is exogenous. ${ }^{16}$ While in principle

12 Note that the mayor is also a voting member of the council. Generally, the mayor is in charge of the administration, preparing all municipal decisions and overseeing their implementation. Also, she often is the town's only full-time working politician.

13 The electoral rules in both states are quite similar. There are, however, also subtle differences. For legislative elections, both states have open-list proportional elections where voters have as many votes as there are seats in the council (which allows for vote-splitting and cross-voting). There are no explicit hurdles for small parties. While BW uses a Sainte-Lague seat allocation mechanism, BAY uses a two-step D'Hondt approach. For executive elections, both states use a two-round majoritarian procedure. If no candidate obtains the absolute majority in the first round, a second election must be held. In BAY, this second election is a classical run-off election between the two leading candidates. In BW, the second election is open (even new candidates are allowed) and first-past-the-post.

14 Exceptions to this rule arise when mayoral terms end prematurely. In that case, a Bavarian municipality might hold an independent executive election for one term, with the requirement to align with the state wide election dates again in the subsequent election.

15 The number of elections in BW increases slightly over time as it becomes easier to obtain all necessary information in later years.

16 No option for premature elections exists for the legislative branch. As no formal coalition agreements are negotiated at the local level, a municipal government cannot break down. If a council member dies in office or resigns for personal reasons, she is replaced automatically with a successor. These successors are determined during the election and consist of candidates which exhibited sufficient votes but have not been allocated seats in the local council due to the D'Hondt allocation mechanism. 
Figure 1: Number of legislative and executive elections in BAY and BW

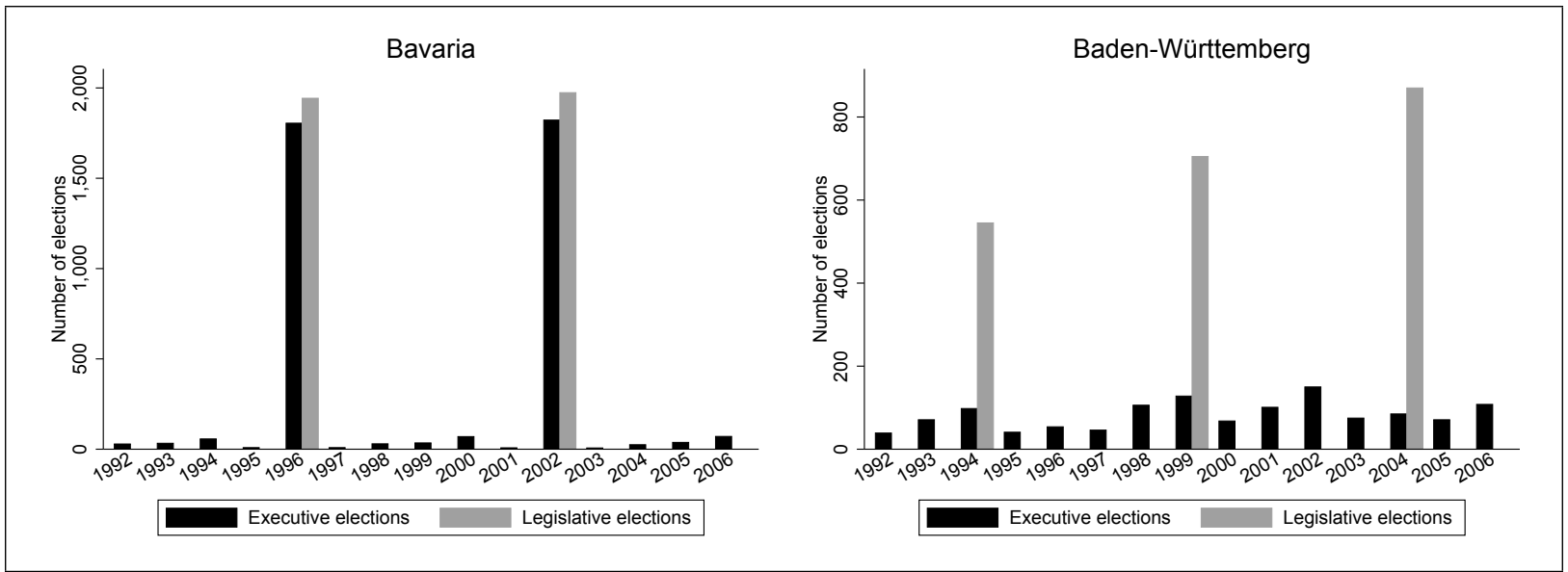

the same also is true for executive elections, the mayor's term may potentially deviate from the general rule. In particular, the mayor's term may end prematurely for a number of reasons. First, the citizens or the council may recall the mayor. ${ }^{17}$ Second, the mayor may die or resign for personal (e.g., sickness) or political (e.g., lack of political support) reasons. A third reason causing deviations from the predefined length of political terms is given by the existence of strict age limits preventing incumbents from serving beyond the age of 68 in $\mathrm{BW} .^{18}$

With respect to expenditures, local governments play important roles in the provision of public services. Municipalities in both states are responsible for roughly $50 \%$ of all public spending in the state (see Federal Statistical Office, 2011). ${ }^{19}$ Among other things, municipalities are in charge of general administration, public order, cultural expenditures, infrastructure, and public transport. In addition, towns often oversee local public firms and administer expenditures from higher-level governmental tiers (e.g., expenditures on social welfare). Despite the often complex division of tasks between the different governmental tiers, municipalities retain considerable discretion in spending decisions.

Focusing on BAY and BW in a sub-national study of PBCs is attractive for several reasons. First, historically, both states have had direct executive elections since the end of World War II. That contrasts with all other German states, which introduced direct elections to the executive branch only in the mid-1990s (see Ade and Freier, 2013; Garmann, 2015; Hessami, 2018). Consequently, we cannot study individual PBCs in executive and legislative elections in other states earlier than the 2000s. ${ }^{20}$ Furthermore, since the mayor is automatically a

\footnotetext{
17 While recall is a constitutionally guaranteed right of the citizens and the council, we almost never observe such an event during the period covered in this study.

18 We further discuss the importance of premature executive elections in our section on identification (see Section 5).

19 Municipalities in BW are responsible for $52.9 \%$ of all state expenditures, which exceeds the German average (including municipal budgets as well as public companies under the control of local towns). Municipalities in BAY administer $49.7 \%$ of total state spending.

20 And even then, evidence from those other German states would be particular as their direct executive elections were introduced very recently.
} 
voting member of the council in both states, studying the overlap of individual cycles is particularly interesting, as the institutional setting may leave room for collusion between the elected branches of government.

Second, the constitutional framework that governs the affairs of the local level follows a comparable standard in BAY and BW. Both states operate in a constitutional setting that is referred to as Süddeutsche Ratsverfassung. Important for our study, that particular constitutional setting grants extensive rights and duties to the head of the executive branch, again standing partly in contrast to the institutional structures of other German states, in particular with respect to expenditures.

Third, the two states in our analysis are comparable along many other dimensions. Both are located in the south of Germany. In addition, both states have had conservative state rule throughout the time covered in this study. ${ }^{21}$ The two states are of comparable size and population. ${ }^{22}$ Finally, BAY and BW are of comparable wealth and industrial performance. ${ }^{23}$ In both states, the municipalities are well off financially, the level of public debt is comparatively low, and the towns enjoy extensive financial liberties. ${ }^{24}$

\section{Theoretical considerations}

In order to derive testable hypotheses, it is necessary to take a more detailed look at the precise relation between the legislative and the executive branches as well as the distribution of powers and duties. In addition to being a voting member and head of the legislative body, the executive also serves as the principal agenda setter. She initially has the sole right to cancel or put topics on the political agenda and is free to rearrange the order of voting on those topics during legislative meetings.

Based on an informal application, which must be supported by a minimum of one-fourth of the regular members of the legislative body, however, the executive branch may lose the exclusive right to be the agenda setter. In such a case, the members of the legislative also gain the right to put topics for consideration on the agenda. The potential range of these topics is only mildly restricted and may not involve topics that are explicitly assigned by law to the executive branch. ${ }^{25}$ The final agenda always must be made public prior to

21 BAY was governed by absolute majorities of the Conservative Party throughout the period covered by this study. In BW, the Conservative Party also headed the state's government; however, it did so as the predominant member of a coalition.

22 Consequently, the municipal structures are quite similar. While BW has slightly larger municipalities on average, the differences are rather small compared to other German states. Together, the two states account for more than $25 \%$ of the German population.

23 Together they account for approximately $75 \%$ of total state redistribution under the German fiscal equalization scheme (see Heinemann et al., 2015).

24 Municipalities in other German states might have very limited financial opportunities for extraordinary investment projects or other general pork barrel spending before elections.

25 The latter, for instance, involves issues regarding public administration. 
the respective legislative meeting. Generally, the legislative branch may take decisions by absolute majorities. Consequently, the legislative branch may not only put new topics on the agenda, but also may overrule the executive by voting on them. In order to balance powers, the executive has the right to veto decisions taken by the legislative branch if they are deemed to be at the expense of the general welfare of the municipality. Furthermore, the executive is obligated to cast a veto if the decision is determined to be illegal. But it can only do so once a decision has been taken and may not prevent topics from being placed on the agenda in advance. Crucial in this context, the legislative branch may even overrule a veto by the executive if the latter was expected to affect municipal welfare negatively. That can be done by putting the respective topic on the agenda once again.

A feature of executive elections at the local level in Germany is that electoral campaigns and their public perceptions usually focus on the individual candidate rather than the political party (which is more important at higher governmental levels). Consequently, if PBCs are implemented to signal competence, the incumbency status of the executive is likely to alter the probability of observing political budget cycles induced by the executive. ${ }^{26}$

One can therefore summarise that the executive branches in BAY and BW generally hold key positions in the context of municipal fiscal decision making, especially in comparison to other federal states in Germany. However, the executive branch does not have sole responsibility for municipal finances. Indeed, relative to the legislative branch, the executive is in a slightly weaker position.

Apart from the institutional setting, we need to make assumptions about the type of PBCs we believe are prevalent in order to deduce testable hypotheses. Even though we view the contribution of this paper to be in the empirical identification of the effects, structuring the theoretical considerations helps considerably to interpret the results properly.

First, we assume that politicians (mayors or the council members) find it worthwhile to manipulate fiscal aggregates prior to elections. While that might be because voters are agnostic (the Nordhaus-type of models) or this represents a mechanism to signal competence (the Rogoff-type model), past research has documented that generally this type of behaviour matters and we have no reason to believe otherwise. It is important to note, that while general PBCs can be explained by both type of models, the mechanism for heterogeneous effects when the incumbent mayor re-runs for office aligns only with the Rogoff-type models of competence signaling.

Second, like much of the literature, we presume that voters care for more spending rather than less. That is to say, voters are not fiscally conservative. Although voters' motivations

26 One careful referee raised the issue that mayors could in fact have incentives to signal competence even when not running for office again. If they hope to be elected in a different municipality, they may still opt to increase spending. Reassuringly, the number of such cases is not large in our dataset. $98 \%$ of the candidates in our sample run for election only in a single municipality. We further want to note, however, that as those switching candidates are included in the baseline model (coded as not re-running), any positive spending effect for them would represent a lower-bound and conservative estimate. 
ultimately remain an assumption, we believe that the literature provides us with ample evidence that that is the case for German local elections (more so than for Swiss or US voters). Most importantly, Asatryan et al. (2017) show that the introduction of direct democracy at the local level in Germany is associated with more public spending and document that local German voters do not seem to be fiscally conservative. Freier (2015) shows that mayors - comprising those of towns included in our sample - achieve a significant increase in the incumbency advantage when raising spending over and above the median level increase. At the same time, an upsurge in debt does not significantly alter the re-election chances. Also the evidence on local German tax increases being shifted to post-election years brought forward by Foremny and Riedel (2014) is corroborative for the lack of fiscal conservatism observed in German local elections.

Based on the foregoing assumptions and given the institutional features, we propose the following three hypotheses 1, 2 and 3.

Hypothesis 1. Both the legislative and the executive branches have the opportunities and the incentives to engage in strategic spending around municipal elections with the aim of gaining electoral advantages.

Hypothesis 2. Relative to the executive branch, cycles for the legislative branch should be more pronounced.

Hypothesis 3. The likelihood of observing political budget cycles in the executive branch should be strengthened if the incumbent seeks re-election to office.

Given the institutional framework, overlapping mayoral and council elections represent special situations and should cause an alteration in the incentives faced by both the legislative and the executive bodies. Based on the implicit assumption that pre-electoral spending is perceived by the electorate as a signal of competence, overlapping elections will result in a setting in which observed signals cannot be associated perfectly with either of the two political actors. We assume that the electorate is likely to reward both branches, which increases the incentives for collusion between both political spheres. ${ }^{27}$ Compared to situations in which election dates diverge, the executive may now free-ride on the legislative election as the incentives for the legislative branch to support rather than overrule projects initiated by

\footnotetext{
27 We would argue that it is indeed very likely that both branches can claim (at least partial) credit. That is particularly the case because local mayors and local council members face much higher degrees of direct political exposure to one another than they do at higher levels of government. We therefore assume that mayors and councils can solve any emerging free-rider problems or credit-claiming issues. If voters attribute spending to a particular politician and reward her accordingly, the resulting incentives could well produce the opposite results in which, e.g., a mayor would spend more only when she receives all of the credit in her stand-alone election. While we cannot rule out that credit-claiming or free-rider issues exist, we thank a careful referee by noting that any remaining credit-claiming issue means that we estimate a lower bound of the effect stemming from hypothesis 4 .
} 
the executive are strengthened significantly. That conclusion is summarised in hypothesis 4.

Hypothesis 4. In case of overlapping elections, observed budget cycles should generally be more pronounced. The effect should be further increased if the executive seeks re-election to office.

\section{Data}

We use data from municipalities in BAY and BW from 1992 to $2006 .{ }^{28}$ We observe 2,056 municipalities and a population of 12.5 million inhabitants in BAY and 10.5 million inhabitants living in 1,101 municipalities in BW.

We obtained information on our outcome variable (total expenditures), state transfers, the results of legislative elections, information on local population as well as population structure from the respective state statistical offices. We calculate municipal expenditures net of transfers, i.e., we subtract the amount of transfers from the respective state government from gross expenditures. That step is crucial in order to capture and isolate the discretionary amount of municipal spending and to eliminate confounding influences, such as spending that is initiated by an upper level governmental tier, but only administered at the municipal level. For instance, the latter could even be induced by PBCs in state level elections (see Furdas et al., 2015).

We create dummy variables that identify a council's pre-election, election, or post-election year to capture the legislative PBC. Furthermore, we classify councils by the share of seats held by leftwing parties (members of the Social Democratic Party, SPD, and the Green Party, Grüne). We summarise all relevant descriptive information in Table 1. We explain our variable coding further in Table A.2 in the appendix.

Obtaining comprehensive data on executive elections in BW is a challenging task. While complete administrative data on elections is provided for BAY by the state statistical office, such data do not exist for BW. ${ }^{29}$ Due to the lack of official data, we collected data manually by contacting and surveying all 1,101 municipalities with respect to the dates of past executive elections. Using the responses obtained, we then searched regional newspapers as well as official announcements (Staatsanzeiger Baden-Württemberg) to gather additional

28 The time coverage of this study is limited by the availability of data on municipal spending (Jahresrechnungstatistik). Additionally, data for earlier executive elections in BW are hard to obtain, thus preventing the coverage from being expanded. Data beyond 2006 cannot be used to estimate electoral cycles because in 2007, municipalities in BAY changed accounting standards. This change was implemented at endogenous points in time in each municipality, which opens up opportunities to manipulate the observable budget strategically around election years.

29 We contacted all major authorities, including the state statistical office, the association of municipalities, the state ministry of interior affairs and the state election office. No summary of official data exists for mayoral elections in BW. 
information on specific elections, e.g., the name, age, party affiliation and regular occupation of the elected mayor as well as information on whether the incumbent mayor ran for re-election. Finally, we conducted an intensive search of official websites and free internet resources to fill other gaps in our data set.

Similar to legislative elections, we code a set of dummy variables for executive elections indicating the pre-election, election, and post-election year in each municipality. Furthermore, we construct dummy variables for mayors indicating affiliation with one of the two leftwing parties mentioned previously, whether the mayor serves in a full-time position, and whether the incumbent mayor sought re-election in the current election. ${ }^{30}$ As the incentives to manipulate public spending strategically should especially be stronger in case of the latter, we will construct respective interactions in order to capture the impact on the formation of PBCs. Finally, we enter the mayor's age as a further control variable in our regressions, which also will be relevant against the background of our instrumental variables approach.

Compared to the total of 1,101 municipalities in BW and 16,515 municipal-year observations, we ultimately obtained adequate information on executive elections for 968 municipalities and significantly fewer years, namely a total of 10,531 municipal-year observations. Typically small municipalities are lost due to missing information. That smaller sample is explained by our research strategy, which was based on a questionnaire that smaller municipalities with fewer municipal staff might not be able to answer. However, we argue that our results do not suffer from a bias given that the differences in the means of control variables between the two groups are rather small (see Table A.3 in the appendix).

Mayoral terms may end prematurely because of the resignation or death of the incumbent mayor. Because those events may potentially pose problems for the identification of electoral cycles, we exclude non-completed or prematurely ended political terms from our baseline specification. When testing the robustness of our main results, we also run estimations in which we include all available observations, including incomplete terms.

${ }_{30}$ About $60 \%$ of the mayors in the sample work full-time. To test the sensitivity of our results, we also tested models in which we focus exclusively on full-time mayors. Those results return similar point estimates, both in sign and magnitude. Because of the significantly smaller sample size, however, the statistical significances of those estimates are not comparable to those reported in the main text (results are available upon request). 


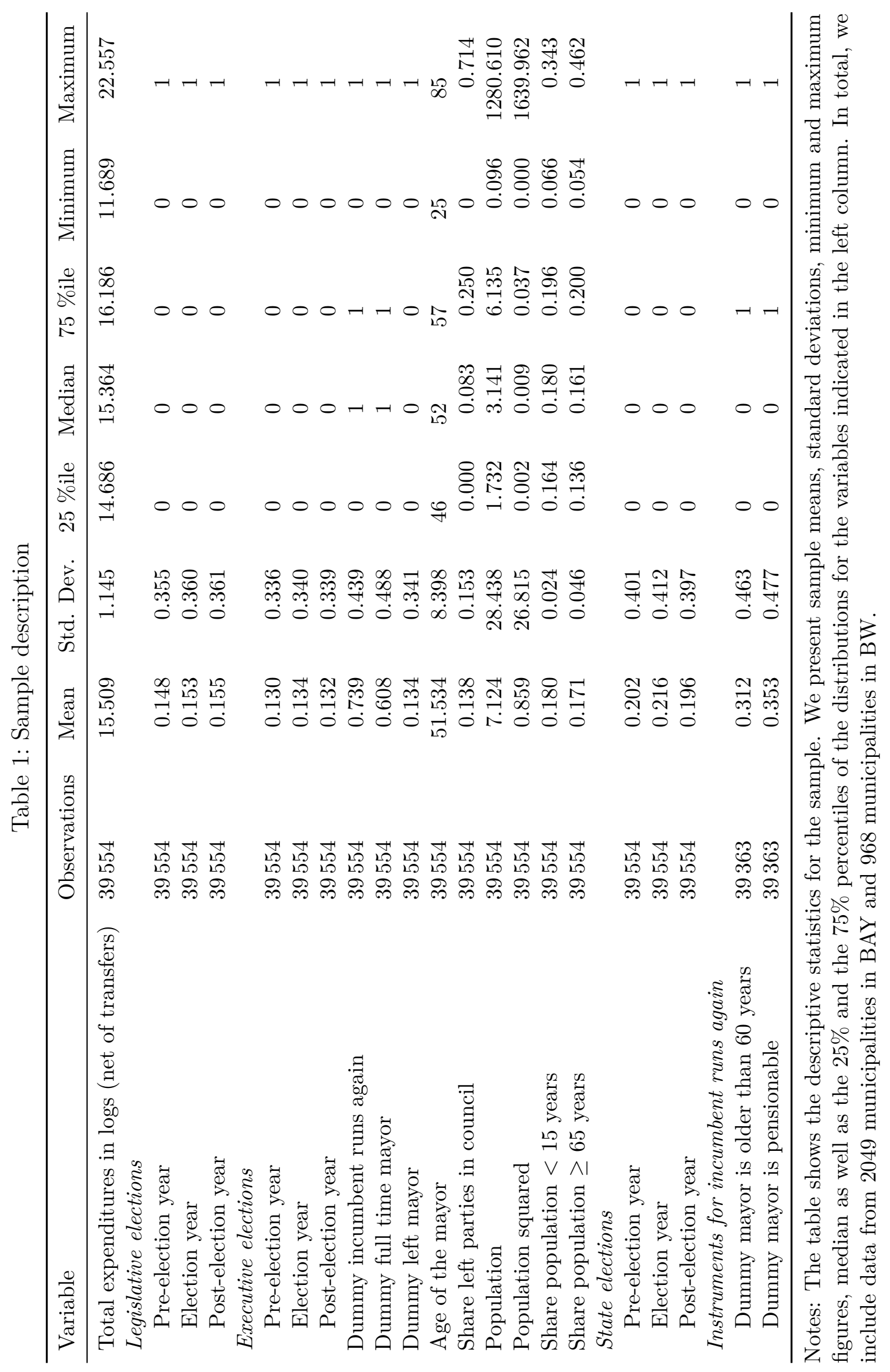




\section{Identification}

We specify the following baseline model to identify political budget cycles in municipal expenditures:

$$
\begin{aligned}
\log \left(Y_{i, t}\right)= & \mathbf{t}_{\mathbf{i}}^{\prime \mathbf{l}} \boldsymbol{\delta}+\mathbf{t}_{\mathbf{i}}^{\prime \mathbf{e}} \boldsymbol{\phi}+I_{i, t} \theta+\sum_{k=-1}^{1}\left(t_{i, t+k}^{l} \times t_{i, t+k}^{e}\right) \beta_{k+2}+\sum_{k=-1}^{1}\left(t_{i, t+k}^{e} \times I_{i, t}\right) \tau_{k+2} \\
& +\sum_{k=-1}^{1}\left(t_{i, t+k}^{l} \times I_{i, t}\right) \pi_{k+2}+\sum_{k=-1}^{1}\left(t_{i, t+k}^{l} \times t_{i, t+k}^{e} \times I_{i, t}\right) \sigma_{k+2}+\mathbf{X}_{\mathbf{i}, \mathbf{t}}^{\prime} \boldsymbol{\gamma} \\
& +\lambda_{t}+\mu_{i}+h(t, s)+\epsilon_{i, t} .
\end{aligned}
$$

The dependent variable is the natural logarithm of total municipal expenditures, net of transfers, $Y_{i, t}$. The vectors $\mathbf{t}^{\prime \prime}$ and $\mathbf{t}^{\prime \mathbf{e}}$ contain dummies capturing election dates in legislative $(l)$ and executive $(e)$ branch elections, respectively. In particular, we define the following dummy variables for the respective elections $j=l, e$ as

$$
\mathbf{t}^{\prime \mathbf{j}}=\left[\begin{array}{c}
t_{t-1}^{j} \\
t_{t}^{j} \\
t_{t+1}^{j}
\end{array}\right] \text { and }\left\{\begin{array}{l}
=1 \text { in the pre-election year, } 0 \text { otherwise } \\
=1 \text { in the election year, } 0 \text { otherwise } \\
=1 \text { in the post-election year, } 0 \text { otherwise. }
\end{array}\right.
$$

To test for differences in spending when election cycles overlap, we estimate interaction terms for congruent pre-, post-, and election years as in Foremny and Riedel (2014). The dummy variable $I_{i, t}$ denotes whether the incumbent mayor seeks re-election at the next election. The indicator is set to zero/one for the whole term, i.e., we assume that the mayor already knows whether she will run for office again at the end of her term when she takes office. ${ }^{31}$ As a result, the estimated coefficient on the incumbent indicator reveals spending differences only between electoral periods. The estimation of interaction terms with the mayoral election dummies then allows separating general from specific incumbent effects in times of elections. Finally, the triple interactions capture the effects of overlapping electoral cycles conditional on the incumbent's decision to seek re-election.

We include general year $\left(\lambda_{t}\right)$ and municipality $\left(\mu_{i}\right)$ fixed effects in the model as well as allow for state-specific linear and quadratic time trends, which we denote by $h(t, s) .{ }^{32}$ Additional control variables are denoted by $\mathbf{X}_{\mathbf{i}, \mathbf{t}}^{\prime}$ and include population, population squared (to control for non-linear effects of local population sizes), demographic variables, state election indicators, ideological proxies for both the executive and the legislative branch,

31 We assume that the mayor, at least, has some preferences about that decision, which leads to a final decision at the end of her term. Note that without adopting that assumption, we would condition the incumbent dummy on election years only, which would render separating general from specific incumbent effects infeasible.

32 We also experimented with state-specific year effects, which eliminates the identification of the council election effects. However, such a model can still identify mayoral and joint election effects and when we do this the results remain reassuringly similar (results not reported). 
the age of the mayor and a dummy variable indicating whether the mayor is a full-time politician.

It is important to highlight how our estimation specification identifies PBCs in legislative and executive branch elections. Because legislative elections in BAY and BW are held in different years, the effects of legislative cycles can be separated from general year effects and from state-specific time trends. In contrast, the identification for the executive branch elections is more demanding. As discussed in Section 2, executive elections in BAY generally are held at the same time as legislative elections, with a few exceptions. In BW, however, we observe executive elections across all years independently of legislative elections. That is the source of variation, including overlapping as well as non-overlapping elections, that we exploit in order to identify individual executive election cycles.

A further important condition for the identification of cycles is the exogeneity of election dates. In case of legislative elections, terms are predetermined by state regulations and cannot be influenced by individual municipalities. While for executive elections that also is generally true, the municipality (and/or the mayor) may influence the timing of elections within limits. ${ }^{33}$ In our baseline specification, we therefore decided to rely exclusively on fully completed executive election terms. This ensures that election dates are exogenous and predetermined exclusively by state regulation (eight years in BW and six years in BAY). In the robustness section, we test the sensitivity of our results by including terms that ended prematurely. The results remain unafected both in terms of size and significance.

Another issue that might be raised with respect to endogeneity is given by the incumbent's decision to seek re-election. In particular, if that decision is linked directly to the fiscal conditions of the municipality and the availability of sufficient financial means for strategic spending, our estimates could not be interpreted as causal. For instance, if a fiscal shock hits the municipality shortly before an election absorbing available financial means initially intended for strategic spending and ultimately inducing the incumbent not to seek re-election, we would falsely attribute pre-election variation in spending to executive cycles in cases of incumbents not re-running for office. ${ }^{34}$ To deal with such potential endogeneity formally, we follow an instrumental variables approach.

To that end, we use two different instruments (explained below) to account for the potential endogeneity of the incumbency indicator. However, implementing an instrumen-

33 In particular, the term of the mayor may end prematurely if 1 ) the citizens or the council recall a mayor (which is an extremely rare event); 2) the mayor dies or resigns owing to sickness (arguably exogenous to our application); or 3) the mayor resigns for other reasons (personal or political reasons). It is clear that a mayor will not return to office if his or her term ends prematurely because of resignation. One potential reason for resignations in our data is given by mayors taking office in a larger city for greater remuneration. While the decision to run for office in another municipality potentially is endogenous, the timing is again exogenous because it is predetermined by the timing of elections in other towns.

34 Note that a potential incompetency of the incumbent would not cause such a pattern. This is the case as incompetency would influence the municipal fiscal position negatively throughout the whole term and is not necessarily confined to the years around an election. 
tal variables approach in the context of our estimation specification (see equation (1)) is challenging because the incumbency variable enters both as individual and as interaction variable. As such, first-stage regressions are necessary to instrument for the single variable and its interaction terms. The procedure is shown in Equations (3.1) to (4) for the interaction of the incumbent dummy and the executive election dummies. In a first step, we separately regress the incumbent dummy (equation (3.1)) and its interactions with the executive election dummies (equation (3.2)) on a set of instruments, i.e., the single instruments $\mathbf{Z}_{\mathbf{i}, \mathbf{t}}$, their interactions with the executive election dummies $\left(\mathbf{t}_{\mathbf{i}}^{\prime \mathbf{e}} \times \mathbf{Z}_{\mathbf{i}, \mathbf{t}}\right)$, and the full set of the remaining covariates $\mathbf{C}_{\mathbf{i}, \mathbf{t}}^{\prime}$. In a subsequent step, we use the predicted values for the incumbent indicator and its interactions as regressors in the second stage regression (equation (4), see Angrist and Pischke (2009, p. 190ff) and Wooldridge (2010, p. 267f) for more information). ${ }^{35}$

$$
\begin{array}{r}
I_{i, t}=\mathbf{t}_{\mathbf{i}}^{\prime \mathbf{\alpha}} \boldsymbol{\alpha}_{\mathbf{1}}+\mathbf{t}_{\mathbf{i}}^{\prime \mathbf{e}} \boldsymbol{\alpha}_{\mathbf{2}}+\mathbf{Z}_{\mathbf{i}, \mathbf{t}} \boldsymbol{\alpha}_{\mathbf{3}}+\left(\mathbf{t}_{\mathbf{i}}^{\prime \mathbf{e}} \times \mathbf{Z}_{\mathbf{i}, \mathbf{t}}\right) \boldsymbol{\alpha}_{\mathbf{4}}+\mathbf{C}_{\mathbf{i}, \mathbf{t}}^{\prime} \boldsymbol{\alpha}_{\mathbf{5}}+\xi_{i, t} \\
\left(\mathbf{t}_{\mathbf{i}}^{\prime \mathbf{e}} \times I_{i, t}\right) \equiv \mathbf{T I}_{\mathbf{i}}=\mathbf{t}_{\mathbf{i}}^{\prime \prime} \boldsymbol{\kappa}_{\mathbf{1}}+\mathbf{t}_{\mathbf{i}}^{\prime \mathrm{e}} \boldsymbol{\kappa}_{\mathbf{2}}+\mathbf{Z}_{\mathbf{i}, \mathbf{t}} \boldsymbol{\kappa}_{\mathbf{3}}+\left(\mathbf{t}_{\mathbf{i}}^{\prime \mathbf{e}} \times \mathbf{Z}_{\mathbf{i}, \mathbf{t}}\right) \boldsymbol{\kappa}_{\mathbf{4}}+\mathbf{C}_{\mathbf{i}, \mathbf{t}}^{\prime} \boldsymbol{\kappa}_{\mathbf{5}}+\varsigma_{i, t} \\
\log \left(Y_{i, t}\right)=\mathbf{t}_{\mathbf{i}}^{\prime \mathbf{}} \boldsymbol{\delta}+\mathbf{t}_{\mathbf{i}}^{\prime \mathbf{e}} \boldsymbol{\phi}+\widehat{I}_{i} \theta+\widehat{\mathbf{T I}}_{\mathbf{i}} \boldsymbol{\pi}+\mathbf{X}_{\mathbf{i}, \mathbf{t}}^{\prime} \boldsymbol{\gamma}+\lambda_{t}+\mu_{i}+h(t, s)+\epsilon_{i, t}
\end{array}
$$

Fortunately, the institutional design allows us to construct a set of instruments to obtain consistent estimates, as they are uncorrelated with the error term of equation (1), but highly correlated with the incumbent's decision to seek re-election. We use the following variables and their interactions with the election dummies to instrument the incumbent indicator, all of which we derived from a careful exploitation of the features of the municipal electoral law. ${ }^{36}$

First, we create a dummy variable that is set to one if the mayor is eligible to receive a pension (dummy mayor is pensionable). In both states, in general, the mayor is eligible to receive a pension only if she has served as a temporary civil servant for a particular number of years and has completed at least one entire term of elective office. ${ }^{37}$

35 One might falsely consider estimating the first stage regression exclusively for the single instrument and the incumbent dummy and then compute the interaction term for the second stage regression manually by using the predicted values of the incumbency indicator. That procedure, however, will produce inconsistent estimates. The results of the first stage regression for the incumbent dummy are presented in Table A.6 in the appendix. The results of the remaining first stage regressions for the interaction terms are available upon request. In equations 3.1 and 3.2 , municipalty and time fixed effects as well as the state-specific time trends are summarised by $\mathbf{C}_{\mathbf{i}, \mathbf{t}}^{\prime} \equiv \mathbf{X}_{\mathbf{i}, \mathbf{t}}^{\prime}+\lambda_{t}+\mu_{i}+h(t, s)$.

36 Again, as for the incumbent seeks re-election dummy, both indicators are equal to zero/one for the full term of office.

37 In BAY, the mayor is eligible to receive a pension if she has served as a mayor for two complete terms and was not re-elected at the next election or refused to accept election. In BW, the rule is more complex: The mayor is eligible to receive a pension if she has completed one full term and fulfills one of three criteria: a) she has served as a temporary civil servant (including positions in the public sector, but not necessarily as a mayor) for 18 years and is older than 47 years of age in the election year; b) has served 
Second, we create a dummy variable that is equal to one if the mayor is older than 60 in the year of the executive election (dummy mayor is older than 60 years). That age threshold is motivated both by the age distribution of incumbent mayors not seeking re-election (see Figure 2) and the general average age of retirement in the western German population. Concerning the latter, the average pensionable age of men in the western states of Germany (including BAY and BW) in the 1990-2006 period was 60.31 years (German Federal Pension Fund, 2014). ${ }^{38}$ The threshold is confirmed by our data, incumbent mayors are significantly less likely to seek re-election if they are older than 60 years of age (see left panel of Figure 2) and while no official age threshold has been established, retirements start to rise at 60 years (see right panel of Figure 2). Checking the sensitivity of our results, we find that they are robust to changes in the precise definition of the age threshold.

Figure 2: Age distribution for mayors who do not re-run for office in the election year

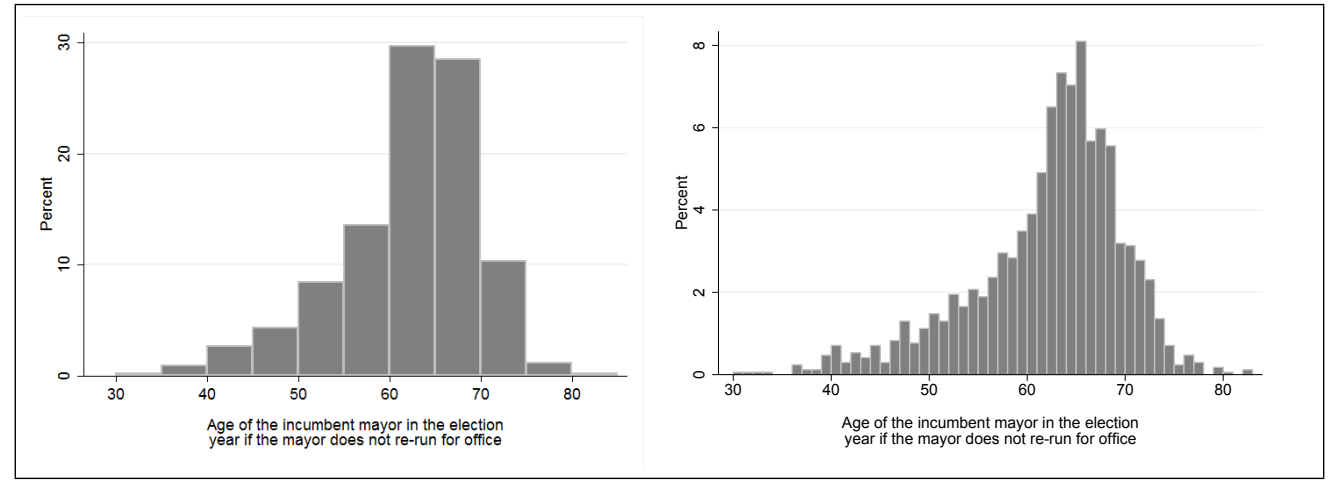

The two instruments we construct fulfill both necessary conditions for an instrumental variables regression: they are relevant in terms of explaining the incumbent's decision to run for re-election (mayors above the age of 60 years and mayors who are eligible to receive pensions have weaker incentives to seek re-election), but are exogenous to local expenditures. In case of the latter, no direct link exists between pension eligibility and public spending. With respect to the mayor's age, in contrast, one might argue that older mayors have different preferences shaping their spending behavior. However, we account for that possibility by controlling explicitly for the mayor's age in the regressions. ${ }^{39}$ Also, tests for overidentification support the appropriateness of our instruments.

as a mayor for two complete terms (=16 years); or c) has served as a mayor for eight years and is older than 60 years of age in the election year. For further details see Article $21 \mathrm{KWBG}$ (Law on local elections and public servants) (BAY) and §36ff LBG (Law on state public servants) (BW).

38 We refer to men only because the vast majority of mayors are men. The figure increases only slightly if women are taken into account.

39 Note that age is insignificant throughout all specifications (see Table A.5 in the appendix). 


\section{Results}

Table 2 presents the main results of our estimations using the above described instrumental variable approach. The results of the fixed effects OLS regression are reported in Table A.4 in the appendix for comparison purposes. ${ }^{40}$ Stepwise, the table develops our full model (column 6). In columns (1) and (2), we specify simple PBC models in which we study legislative and executive election effects separately. While column (1) shows the results for the legislative elections, effects of the executive elections are modeled in column (2). In column (3), we incorporate both cycles into one model. In column (4), we also estimate the interactions between joint legislative and executive election years and explore the effects of overlapping cycles. In column (5), we interact the incumbent dummy with the executive election dummies. Finally, we present the estimation results for the full model in column (6). There, we estimate the effects of overlapping PBCs conditional on the incumbent mayor's decision to run for reelection.

\section{Cycles in the legislative and executive branches}

For legislative elections, we find sizable and statistically significant effects (at the 5 percent level) for the pre-election year across all specifications that are robust to the inclusion of the executive cycle as well as the various interaction effects. The dependent variable is the logarithm of municipal total expenditures (net of transfers); therefore, the coefficients must be interpreted as semi-elasticities. The estimated effects in Table 2 range between 1.4-1.6 percent of total expenditures in the first five columns and are somewhat larger with 4.4 percent in column (6). For a town with 5,000 inhabitants, an effect size of 1.5 percent amounts to about 170,000 Euro in additional expenditures in the year prior to a legislative election.

For executive elections, we do not find evidence of a robust individual cycle in total expenditures. While we do find evidence for unconditional post-election year cycles in executive elections (columns (2) and (3)), that effect disappears once further interaction effects are included. Remaining point estimates of the election dummies in case of executive elections are quite small and statistically insignificant.

With regard to our hypotheses, we can summarise that there is some indication (although not significantly so in all cases) that both levels of government seem to produce some cycles (1) and that the legislative cycles is indeed more pronounced (and more stable) than the executive cycle (2). We now turn the analysis to the effects of incumbency as well as overlaps.

${ }_{40}$ In both tables we report the results for our main variables of interest only (legislative and executive election dummies, the incumbent runs again dummy as well as the various interaction effects). The results for the control variables are presented in the appendix (see Table A.5). Interestingly, statistically significant effects are not found for the mayor's age, the full-time mayor dummy, or either ideology proxies. While increasing population has a concave effect on local expenditures, the shares of young and old people do not affect spending. 
Table 2: PBCs in public expenditure (instrumental variables regression)

\begin{tabular}{|c|c|c|c|c|c|c|}
\hline & \multicolumn{2}{|c|}{$\begin{array}{l}\text { Dependent variable: } \\
(1) \quad(2)\end{array}$} & \multicolumn{4}{|c|}{ 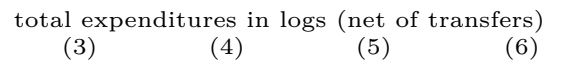 } \\
\hline $\begin{array}{l}\text { Legislative elections } \\
\text { Pre-election year }\end{array}$ & $\begin{array}{c}0.016^{* *} \\
{[2.477]}\end{array}$ & & $\begin{array}{c}0.014^{* *} \\
{[2.194]}\end{array}$ & $\begin{array}{c}0.015^{* *} \\
{[2.266]}\end{array}$ & $\begin{array}{c}0.015^{* *} \\
{[2.293]}\end{array}$ & $\begin{array}{c}0.044^{* *} \\
{[2.103]}\end{array}$ \\
\hline Election year & $\begin{array}{c}0.002 \\
{[0.282]}\end{array}$ & & $\begin{array}{l}-0.001 \\
{[-0.140]}\end{array}$ & $\begin{array}{c}0.001 \\
{[0.138]}\end{array}$ & $\begin{array}{l}-0.001 \\
{[-0.125]}\end{array}$ & $\begin{array}{c}0.012 \\
{[0.639]}\end{array}$ \\
\hline Post-election year & $\begin{array}{c}0.005 \\
{[0.918]}\end{array}$ & & $\begin{array}{l}-0.001 \\
{[-0.145]}\end{array}$ & $\begin{array}{l}-0.004 \\
{[-0.655]}\end{array}$ & $\begin{array}{l}-0.000 \\
{[-0.002]}\end{array}$ & $\begin{array}{l}-0.003 \\
{[-0.216]}\end{array}$ \\
\hline $\begin{array}{l}\text { Executive elections } \\
\quad \text { Pre-election year }\end{array}$ & & $\begin{array}{c}0.003 \\
{[0.786]}\end{array}$ & $\begin{array}{c}0.000 \\
{[0.066]}\end{array}$ & $\begin{array}{c}0.002 \\
{[0.401]}\end{array}$ & $\begin{array}{l}-0.017 \\
{[-1.459]}\end{array}$ & $\begin{array}{c}0.000 \\
{[0.017]}\end{array}$ \\
\hline Election year & & $\begin{array}{c}0.004 \\
{[1.126]}\end{array}$ & $\begin{array}{c}0.005 \\
{[1.129]}\end{array}$ & $\begin{array}{c}0.006 \\
{[0.978]}\end{array}$ & $\begin{array}{c}0.003 \\
{[0.181]}\end{array}$ & $\begin{array}{l}0.036^{*} \\
{[1.726]}\end{array}$ \\
\hline Post-election year & & $\begin{array}{c}0.010^{* * *} \\
{[2.641]}\end{array}$ & $\begin{array}{c}0.010^{* *} \\
{[2.475]}\end{array}$ & $\begin{array}{c}0.007 \\
{[1.310]}\end{array}$ & $\begin{array}{c}0.033 \\
{[1.330]}\end{array}$ & $\begin{array}{l}-0.003 \\
{[-0.138]}\end{array}$ \\
\hline $\begin{array}{l}\text { Executive elections } \times \text { legislative elections } \\
\text { Joint pre-election year }\end{array}$ & & & & $\begin{array}{l}-0.005 \\
{[-0.568]}\end{array}$ & & $\begin{array}{l}-0.049^{*} \\
{[-1.650]}\end{array}$ \\
\hline Joint election year & & & & $\begin{array}{l}-0.004 \\
{[-0.375]}\end{array}$ & & $\begin{array}{l}-0.046^{*} \\
{[-1.854]}\end{array}$ \\
\hline Joint post-election year & & & & $\begin{array}{l}0.008 \\
{[0.855]}\end{array}$ & & $\begin{array}{c}0.068^{* *} \\
{[2.480]}\end{array}$ \\
\hline $\begin{array}{l}\text { Executive elections } \times \text { incumbent runs again } \\
\quad \text { Pre-election year }\end{array}$ & & & & & $\begin{array}{c}0.020 \\
{[1.511]}\end{array}$ & $\begin{array}{c}0.001 \\
{[0.065]}\end{array}$ \\
\hline Election year & & & & & $\begin{array}{c}0.002 \\
{[0.084]}\end{array}$ & $\begin{array}{l}-0.041 \\
{[-1.599]}\end{array}$ \\
\hline Post-election year & & & & & $\begin{array}{l}-0.033 \\
{[-1.036]}\end{array}$ & $\begin{array}{l}0.013 \\
{[0.491]}\end{array}$ \\
\hline $\begin{array}{l}\text { Legislative elections } \times \text { incumbent runs again } \\
\text { Pre-election year }\end{array}$ & & & & & & $\begin{array}{l}-0.034 \\
{[-1.413]}\end{array}$ \\
\hline Election year & & & & & & $\begin{array}{l}-0.013 \\
{[-0.611]}\end{array}$ \\
\hline Post-election year & & & & & & $\begin{array}{l}-0.001 \\
{[-0.042]}\end{array}$ \\
\hline $\begin{array}{l}\text { Joint elections } \times \text { incumbent runs again } \\
\text { Pre-election years }\end{array}$ & & & & & & $\begin{array}{c}0.054 \\
{[1.547]}\end{array}$ \\
\hline Election years & & & & & & $\begin{array}{c}0.057^{* *} \\
{[1.985]}\end{array}$ \\
\hline Post-election years & & & & & & $\begin{array}{r}-0.080^{* *} \\
{[-2.293]}\end{array}$ \\
\hline Incumbent runs again dummy & $\begin{array}{c}0.015 \\
{[1.489]}\end{array}$ & $\begin{array}{c}0.017 \\
{[1.635]}\end{array}$ & $\begin{array}{c}0.017 \\
{[1.617]}\end{array}$ & $\begin{array}{c}0.017 \\
{[1.613]}\end{array}$ & $\begin{array}{c}0.012 \\
{[0.791]}\end{array}$ & $\begin{array}{c}0.017 \\
{[1.111]}\end{array}$ \\
\hline Control variables & $\checkmark$ & $\checkmark$ & $\checkmark$ & $\checkmark$ & $\checkmark$ & $\checkmark$ \\
\hline Observations & 39344 & 39344 & 39344 & 39344 & 39344 & 39344 \\
\hline$R^{2}$ & 0.077 & 0.077 & 0.077 & 0.077 & 0.076 & 0.075 \\
\hline Cluster & 2997 & 2997 & 2997 & 2997 & 2997 & 2997 \\
\hline Underidentification test (Kleibergen-Paap rk LM) & 888.7 & 865.4 & 864.3 & 863.4 & 833.2 & 674.8 \\
\hline Weak identification test (Kleibergen-Paap rk Wald F) & 1066.3 & 1024.9 & 1023.0 & 1021.0 & 150.4 & 49.2 \\
\hline Overidentification test (Hansen J p-value) & 0.824 & 0.851 & 0.850 & 0.848 & 0.977 & 0.755 \\
\hline$A I C$ & -13092.4 & -13090.4 & -13089.4 & -13084.3 & -13054.8 & -12983.9 \\
\hline$S B I C$ & -12826.4 & -12824.4 & -12797.7 & -12766.8 & -12736.3 & -12589.2 \\
\hline
\end{tabular}

Notes: The instrumented variable is the incumbent runs again dummy. Instruments are a dummy indicating whether the mayor is pensionable, a dummy indicating whether the mayor is older than 60 years, and the interactions of the instruments with the election indicators (if used in the regression, see the results of the first stage regression in Table A.6 in the appendix). All specifications include municipality and time fixed effects. Robust t-values are shown in brackets. ***, (**), (*) denotes significance at the 1-, (5-), (10-)\%-level. Error terms are clustered at the municipal level. Interaction effects for election dummies are estimated only for congruent election years. Marginal effects of the interaction effects in columns (5) and (6) are shown in Table 3 . The estimation includes the full set of additional control variables. Source: Own calculations. 


\section{Incumbents seeking re-election}

In the instrumental variable approach, the dummy whether the incumbent seeks re-election (see bottom of table 2) is sizable and positive but remains statistically insignificant (the estimates are statistically significant and positive in the OLS fixed effects specification, see Table A.4 in the appendix). While those results indicate more spending in election periods when the incumbent seeks re-election (especially in the OLS regression), we cannot confirm hypothesis 3 fully based on this evidence.

\section{Overlapping cycles}

While columns (1), (2) and (3) report the results for separate cycles in the two branches of government, the case of overlapping cycles is first highlighted in column (4). There, we include dummies for cases when the two elections are held exactly the same year in a municipality. The results are not fully transparent from the table. The point estimates do not signify any cycles. However, what is important for interpretation are not the individual effects per se, but the combined effects of variables that are turned on for a specific case. Against that background, municipal spending seems to increase in the year following simultaneous elections to both political branches. The combined executive post-election coefficients is $0.015^{* *}$ ( $\mathrm{p}$-value $=0.035$, instrumental variables regression). That result points to potential post-election collusion between the two political branches in order to gain electoral advantage (see hypothesis 4).

However, the underlying channel remains unclear in these estimations, which leads us to extend the model further. In columns (5) and (6) of table 2, we augment the model with interactions of a dummy indicating whether or not the incumbent mayor seeks re-election and the cycle variables. ${ }^{41}$

\section{Overlapping cycles and interactions with incumbency effects}

In column (5), we include interactions between incumbent mayors choosing to run for office again and mayoral election dummies, while column (6) reports the results for the full model in which interactions between the incumbency and the election year dummies in both political branches are included. As this is a very complex setting involving multiple interactions such that coefficients can hardly be interpreted in isolation, we refer to Table 3, which presents F-tests of joint significance for the (combination of) estimated effects and therefore is complementary to the present results. We report the F-tests for the OLS model (columns (1) and (2)) to make full comparison possible, however; we will discuss and highlight only the results pertaining to the IV approach (columns (3) and (4)).

\footnotetext{
$\overline{41}$ The same is done for the OLS estimates in table A.4.
} 
The structure of Table 3 is as follows: while distinguishing between pre-election, election, and post-election years, we compute marginal effects for overlapping legislative and executive elections conditional on whether the incumbent mayor runs for re-election. We then test whether the difference between those effects is statistically different from zero. Additionally, we compute the marginal incumbent effect conditional on whether a simultaneous election is held. That effect can then be contrasted to the unconditional effect (incumbent runs again dummy) shown in the two baseline tables.

Most importantly, we want to refer the reader to line $E$ in Table 3 . There, we document a sizable and statistically significant incumbent effect in the range of 3.2-3.8 percent conditional on joint legislative and executive elections the following year. Note that this effect is much larger than the unconditional point estimates presented in Table 2, thus providing clearer evidence in support of hypothesis 3.

The results for executive and legislative elections, conditional on joint election years and the incumbent seeks re-election dummy, are further summarised in Figure $3 .{ }^{42}$ For both branches, we observe a similar pattern for joint pre-election, election, and post-election years conditional on the incumbent's decision to seek re-election. That is, if the incumbent seeks re-election, spending increases in joint pre-election and joint election years but decreases in joint post-election years. Exactly the opposite holds true if the incumbent does not seek re-election: spending decreases in joint pre-election and joint election years but increases in the year after both elections took place. As a result, we detect sizable positive differences in joint pre-election and joint election years, with meaningful negative differences in joint postelection years. While the individual effects and differences are significant at the 5 percent level for the joint-pre-election year in the executive and for the joint election year in the legislative, the results for the post-election year in the executive branch remain marginally insignificant.

Taken together, municipal expenditures increase in joint pre-election and election years if the incumbent seeks re-election and increase in joint post-election years if she did not. In case of the first two results, one might argue that these are expected as incentives for strategic spending and collusion with the municipal council are highest if the incumbent seeks re-election (hypothesis 4). Furthermore, we observe the pattern that in these settings, with mayors who are not seeking re-election, spending usually decreases. This effect may be justified with shifts in the budget over time rather than deficit spending. As the incentives for strategic spending are highest preceding and contemporary to elections, an incumbent may shift future expenditure to the present causing a decline in post-election expenditure if the mayor seeks re-election. The observation of a positive and statistically significant effect for the legislative as well as executive branch in post-election years conditional on the incumbent not running for office (see also lines $K$ and $M$ in Table 3) may be explained by

$\overline{42}$ The underlying marginal effects and levels of statistical significance all refer to column (4) in Table 3. 
Table 3: Marginal effects of interaction terms: Fixed effects OLS regression vs. instrumental variables regression

\begin{tabular}{|c|c|c|c|c|}
\hline & \multicolumn{2}{|c|}{ Fixed effects OLS } & \multicolumn{2}{|c|}{ Instrumental variables } \\
\hline & (1) & $(2)$ & (3) & (4) \\
\hline $\begin{array}{l}\text { Pre-election year } \\
\quad \text { A: Legislative | joint pre-election years, incumbent runs again }=0\end{array}$ & & $\begin{array}{l}-0.006 \\
{[-0.392]}\end{array}$ & & $\begin{array}{l}-0.005 \\
{[-0.236]}\end{array}$ \\
\hline B: Legislative | joint pre-election years, incumbent runs again $=1$ & & $\begin{array}{l}0.015 \\
{[1.577]}\end{array}$ & & $\begin{array}{c}0.015 \\
{[1.382]}\end{array}$ \\
\hline Difference if incumbent reruns (B-A) & & $\begin{array}{c}0.021 \\
{[1.483]}\end{array}$ & & $\begin{array}{c}0.020 \\
{[0.799]}\end{array}$ \\
\hline C: Executive $\mid$ joint pre-election years, incumbent runs again $=0$ & $\begin{array}{c}-0.018 * * * \\
{[-2.590]}\end{array}$ & $\begin{array}{c}-0.026^{* *} \\
{[-2.126]}\end{array}$ & $\begin{array}{l}-0.017 \\
{[-1.459]}\end{array}$ & $\begin{array}{c}-0.049^{* *} \\
{[-2.138]}\end{array}$ \\
\hline D: Executive | joint pre-election years, incumbent runs again $=1$ & $\begin{array}{c}0.006 \\
{[1.422]}\end{array}$ & $\begin{array}{c}0.004 \\
{[0.584]}\end{array}$ & $\begin{array}{c}0.004 \\
{[0.788]}\end{array}$ & $\begin{array}{c}0.006 \\
{[0.714]}\end{array}$ \\
\hline Difference if incumbent reruns (D-C) & $\begin{array}{l}0.024^{* * *} \\
{[3.209]}\end{array}$ & $\begin{array}{c}0.031^{* *} \\
{[2.437]}\end{array}$ & $\begin{array}{c}0.020 \\
{[1.511]}\end{array}$ & $\begin{array}{c}0.055^{* *} \\
{[2.069]}\end{array}$ \\
\hline E: Incumbent runs again | joint pre-election years & $\begin{array}{l}0.028^{* * *} \\
{[3.325]}\end{array}$ & $\begin{array}{l}0.032^{* * *} \\
{[3.288]}\end{array}$ & $\begin{array}{l}0.032^{*} \\
{[1.834]}\end{array}$ & $\begin{array}{c}0.039^{* *} \\
{[2.009]}\end{array}$ \\
\hline $\begin{array}{l}\text { Election year } \\
\quad \text { F: Legislative | joint election years, incumbent runs again }=0\end{array}$ & & $\begin{array}{l}-0.025^{*} \\
{[-1.902]}\end{array}$ & & $\begin{array}{l}-0.034^{*} \\
{[-1.858]}\end{array}$ \\
\hline G: Legislative | joint election years, incumbent runs again $=1$ & & $\begin{array}{l}0.005 \\
{[0.480]}\end{array}$ & & $\begin{array}{c}0.010 \\
{[0.928]}\end{array}$ \\
\hline Difference if incumbent reruns (G-F) & & $\begin{array}{c}0.030 * * \\
{[2.069]}\end{array}$ & & $\begin{array}{c}0.044^{* *} \\
{[1.983]}\end{array}$ \\
\hline H: Executive $\mid$ joint election years, incumbent runs again $=0$ & $\begin{array}{l}-0.007 \\
{[-0.865]}\end{array}$ & $\begin{array}{l}-0.013 \\
{[-0.980]}\end{array}$ & $\begin{array}{c}0.003 \\
{[0.181]}\end{array}$ & $\begin{array}{l}-0.010 \\
{[-0.408]}\end{array}$ \\
\hline I: Executive | joint election years, incumbent runs again $=1$ & $\begin{array}{c}0.010^{* *} \\
{[2.141]}\end{array}$ & $\begin{array}{l}0.007 \\
{[0.966]}\end{array}$ & $\begin{array}{l}0.005 \\
{[0.881]}\end{array}$ & $\begin{array}{l}0.006 \\
{[0.733]}\end{array}$ \\
\hline Difference if incumbent reruns (H-I) & $\begin{array}{l}0.017^{*} \\
{[1.763]}\end{array}$ & $\begin{array}{c}0.020 \\
{[1.439]}\end{array}$ & $\begin{array}{c}0.002 \\
{[0.084]}\end{array}$ & $\begin{array}{l}0.016 \\
{[0.576]}\end{array}$ \\
\hline $\mathrm{J}$ : Incumbent runs again | joint election years & $\begin{array}{l}0.021^{* * *} \\
{[2.795]}\end{array}$ & $\begin{array}{l}0.029^{* * *} \\
{[3.139]}\end{array}$ & $\begin{array}{c}0.014 \\
{[1.044]}\end{array}$ & $\begin{array}{c}0.021 \\
{[1.355]}\end{array}$ \\
\hline $\begin{array}{l}\text { Post-election year } \\
\quad \text { K: Legislative | joint post-election years, incumbent runs again }=0\end{array}$ & & $\begin{array}{l}0.005 \\
{[0.389]}\end{array}$ & & $\begin{array}{c}0.065^{* *} \\
{[2.369]}\end{array}$ \\
\hline L: Legislative | joint post-election years, incumbent runs again $=1$ & & $\begin{array}{c}0.004 \\
{[0.407]}\end{array}$ & & {$[-0.016$} \\
\hline Difference if incumbent reruns (L-K) & & $\begin{array}{l}-0.002 \\
{[-0.118]}\end{array}$ & & $\begin{array}{c}-0.081^{* *} \\
{[-2.240]}\end{array}$ \\
\hline M: Executive | joint post-election years, incumbent runs again $=0$ & $\begin{array}{l}-0.005 \\
{[-0.626]}\end{array}$ & $\begin{array}{l}0.003 \\
{[0.249]}\end{array}$ & $\begin{array}{l}0.033 \\
{[1.330]}\end{array}$ & $\begin{array}{l}0.065^{*} \\
{[1.953]}\end{array}$ \\
\hline $\mathrm{N}$ : Executive | joint post-election years, incumbent runs again $=1$ & $\begin{array}{c}0.014^{* * *} \\
{[3.098]}\end{array}$ & $\begin{array}{c}0.017^{* *} \\
{[2.281]}\end{array}$ & $\begin{array}{c}0.000 \\
{[0.011]}\end{array}$ & $\begin{array}{l}-0.002 \\
{[-0.175]}\end{array}$ \\
\hline Difference if incumbent reruns (N-M) & $\begin{array}{l}0.019^{*} \\
{[1.940]}\end{array}$ & $\begin{array}{c}0.014 \\
{[1.046]}\end{array}$ & $\begin{array}{l}-0.033 \\
{[-1.036]}\end{array}$ & $\begin{array}{l}-0.067 \\
{[-1.595]}\end{array}$ \\
\hline O: Incumbent runs again | joint post-election years & $\begin{array}{l}0.023^{* * *} \\
{[3.090]}\end{array}$ & $\begin{array}{c}0.023^{* *} \\
{[2.446]}\end{array}$ & $\begin{array}{l}-0.021 \\
{[-1.007]}\end{array}$ & $\begin{array}{l}-0.051 \\
{[-1.560]}\end{array}$ \\
\hline
\end{tabular}

Notes: The marginal effects are computed by using the coefficients of columns (5) and (6) of Table A.4 and Table 2 , respectively. Statistical significance is based on F-tests. t-values are shown in brackets. Marginal effects are computed for overlapping legislative and executive elections conditional on whether the incumbent mayor runs for re-election while distinguishing between pre-election, election, and post-election years. Afterwards, it is tested whether the difference between these effects is statistically different from zero. $*^{* *},(* *),(*)$ denotes significance at the 1-, (5-), (10-)\%-level. Source: Own calculations based on Stata command lincom. 
Figure 3: Marginal effects of executive and legislative elections conditional on joint elections and the incumbent's decision to re-run for office

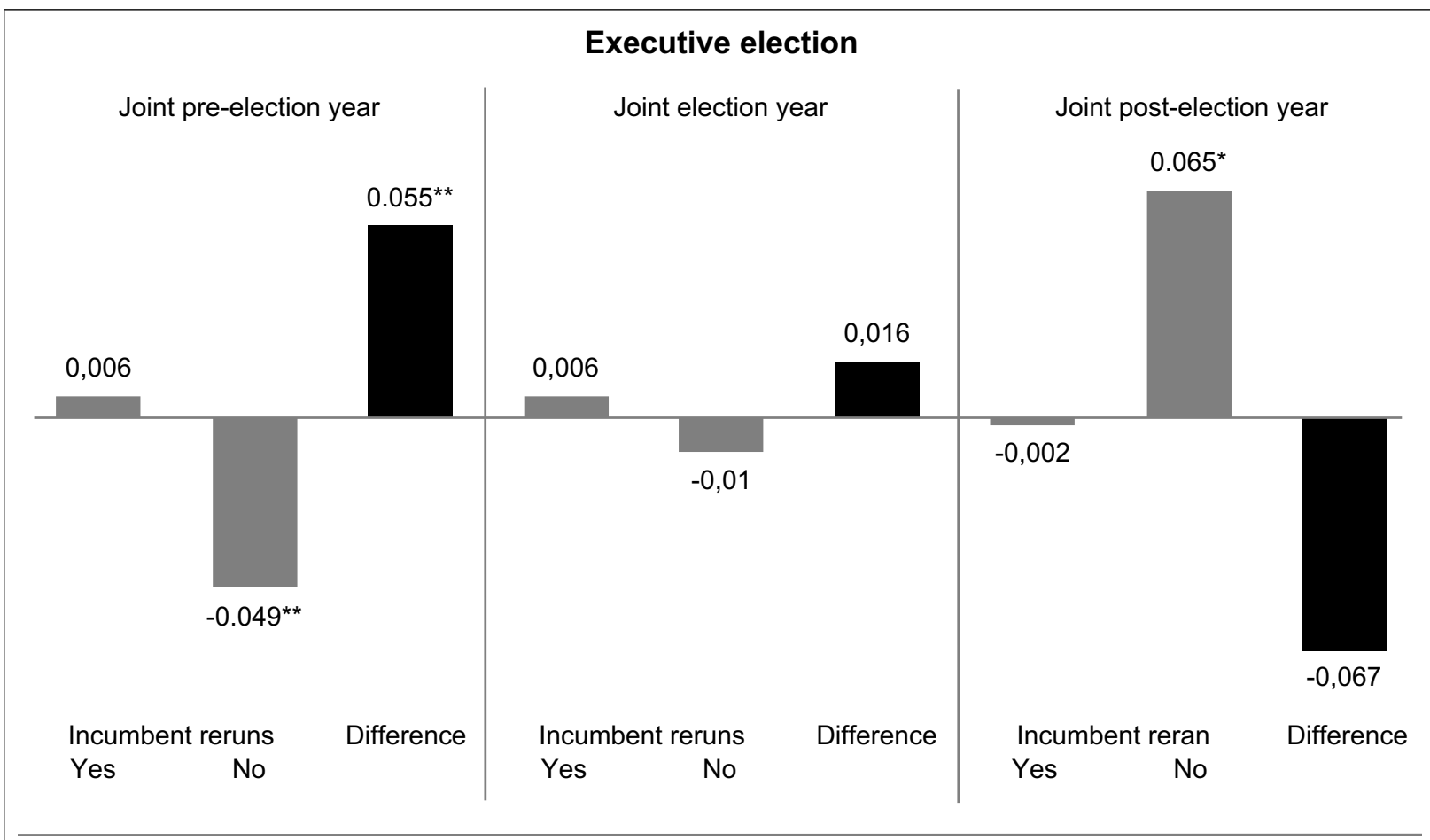

Legislative election

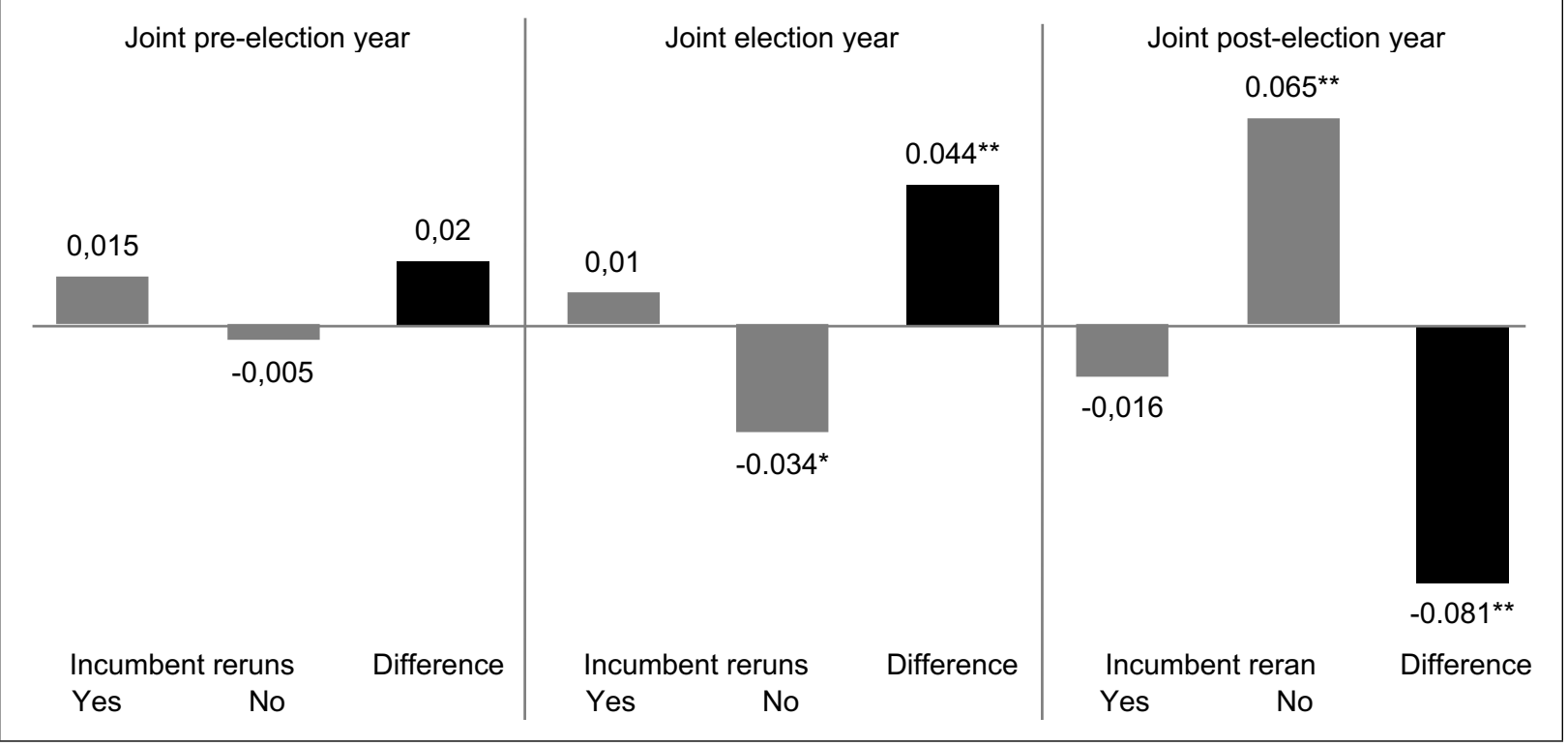

Notes: The figure presents marginal effects of executive (top graph) and legislative (bottom graph) elections conditional on overlapping pre-, post-, and election years and the incumbent runs again dummy. The black bars indicate the difference in spending conditional on the incumbent's decision to re-run for office. Figures at the top/bottom of each bar denote marginal effects which refer to column (4) of Table $\left.3 .{ }^{* * *},{ }^{* *}\right),\left(^{*}\right)$ display significance at the 1-, (5-), (10-)\%-level.

the new mayor in office colluding with the municipal council to initiate investment projects promised throughout her electoral campaign. 


\section{Robustness checks}

We carry out various sensitivity tests to check the robustness of our findings. All tests are carried out for columns (5) and (6) of Table 2. The results are reported in Table 4 (general tests) and Table 5 (specifications with alternative instruments). The letters in italics at the end of the lines correspond to those in Table 3. Only the main results of the previous findings are presented, i.e., we show the unconditional coefficient for legislative pre-election years, the incumbent effect conditional on joint pre-election years, and the difference in spending if the incumbent seeks re-election conditional on joint pre-election, election, and post-election years. All of the estimates include the full set of covariates.

With respect to general tests (Table 4), we first include non-complete mayoral terms periods in the estimation. These periods were excluded from the previous regressions because the timing of executive elections could be endogenous. Second, we exclude county-free cities from the estimation sample. ${ }^{43}$ PBCs in these cities might differ from the full sample because their elections are more partisan than those held in smaller municipalities. Third, to check whether the results are affected by the clustering of the error terms, we alternatively cluster at the county level. Fourth, we re-estimate all specifications for data on gross expenditures, i.e., we add state transfers to municipal expenditures. That may provide further insights into the formation of PBCs, as municipal spending may be co-financed by upper-level governmental tiers. Finally, we take account of the state of the municipal economy by entering the share of employees in the working population as an additional control. ${ }^{44}$ In an additional robustness tests (results not reported), we also implemented a dynamic LSDV specification and found qualitatively similar results even there. ${ }^{45}$

Concerning specifications with alternative instruments (Table 5), we first apply different thresholds of the age dummy. The instrument indicating that the mayor is older than 60 years in the executive election year is replaced by a threshold of 59 years (columns (1) and (2)) and a threshold of 61 years (columns (3) and (4)), respectively. Second, we replace the binary age instrument with a discrete measure and enter the mayor's actual age as an instrument. However, that substitution comes at the expense of controlling for

43 The federal states in Germany are further subdivided into administrative counties. These counties usually subsume several cities. In case of several large cities, however, these form a county on there own and are referred to as county-free cities. BW has 9 county-free cities and BAY has 25 county-free cities.

44 Information on the municipal unemployment rate from the Federal Employment Agency is available only from 1998 onwards.

45 The literature on PBCs has often employed dynamic specifications (solving the estimation issues in GMM methods) because of the persistent nature of expenditures. In the present application, the estimation is complicated further by the fact that we must instrument the incumbent mayor's decision to stand for reelection. We would thus have to solve the dual problem of instrumenting both the lagged endogenous variables and the reelection variable. That is not possible using standard methods for dynamic estimations. For robustness, we opted for the simpler LSDV approach. However, we decided that those results are not very informative as - given our data structure - the resulting Nickel bias cannot be argued to be small. All such estimates are available upon request. 
the direct impact of the mayor's age on public spending. While we do not detect such an impact in the previous regressions (see, e.g., Table A.5), the instrument's exogeneity assumption is weaker than when using the non-linear transformation of the mayor's age along with controlling for a direct effect at the same time. Finally, we estimate our model using a single instrument rather than two as in the previous regressions and rely on the dummy variable indicating whether the mayor is older than 60 in the year of the executive election. This is due to the Bavarian state regulation associated with pension eligibility, i.e., there might be a confounding effect as one condition to become pensionable in BAY is that the incumbent sought re-election (but was not elected or refused to accept her election). Accordingly, an incumbent could strategically decide to seek re-election in order to become pensionable, even though it is not her intention to take office afterwards. However, estimating the instrumental variables regression with only one instrument means that we can no longer test for overidentification.

The results reveal that the findings are highly robust. Both the economic and statistical significance of the unconditional legislative pre-election year effect are confirmed. Furthermore, only minor changes arise with respect to the difference in joint pre-election, election, and post-election years, conditional on whether the incumbent runs for re-election. While the point estimates only change slightly, the statistical significance is lost in legislative election years when we include non-completed election periods or apply a threshold of 59 years for the age instrument (column (2), line $G-F$ in Tables 4 and 5) and in legislative postelection years when we run regressions with only one instrument (column (4), line $L-K$ in Table 5). Furthermore, we lose statistical significance for the conditional incumbent effect when using the mayor's age as an instrument (columns (5) and (6), line $E$ in Table 5).

Overall, our robustness analyses show that the main findings of our study hold up. A reversal in the effect materialises for pre-election and election years compared to post-election years conditional on the incumbent's decision to seek re-election. Expenditures are higher in the year before the election and in the election year if the incumbent runs for re-election and cycles overlap, and increase in post-election years if the incumbent mayor did not run for re-election and elections did overlap. 


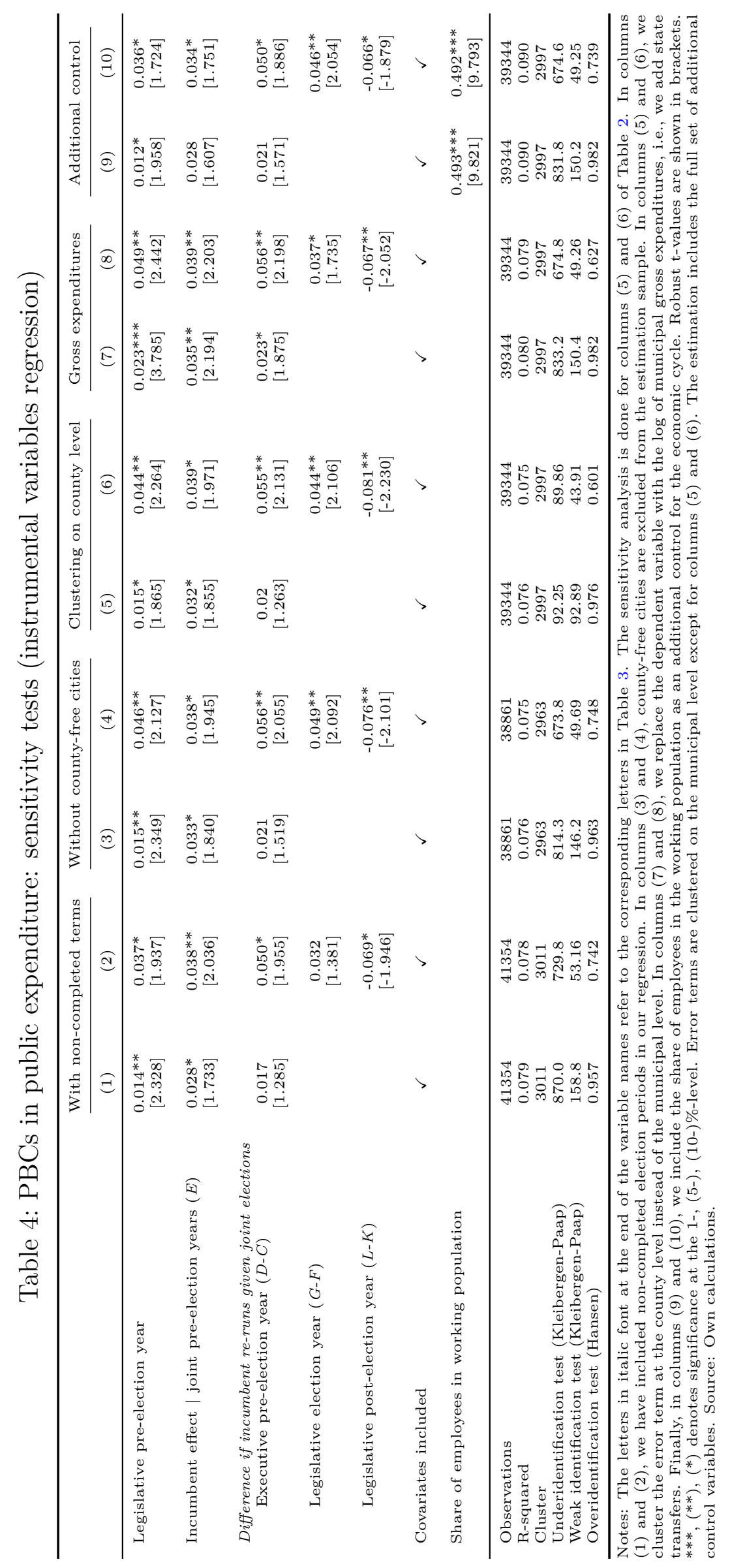




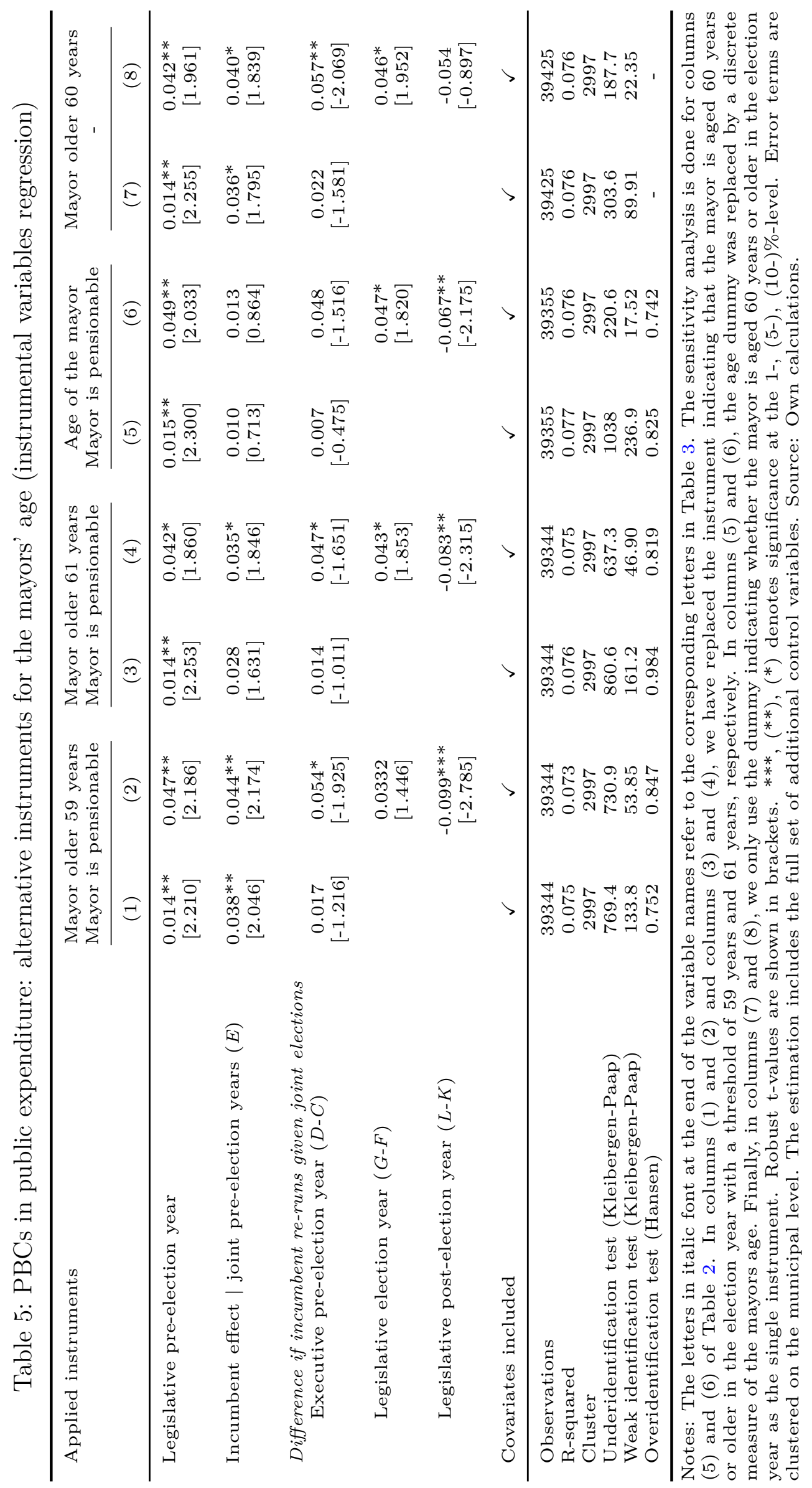




\section{Conclusion}

We study PBCs in expenditures with a particular focus on overlapping election cycles in the executive and legislative branches of local governments. As the literature on PBCs usually cannot separate effects for those two political branches, doing so is a distinct feature of our study. Furthermore, we use an instrumental variable approach to account explicitly for the potential endogeneity of the incumbent mayor's decision to seek re-election and how that decision affects spending at times of elections. Using data from Bavaria and BadenWuerttemberg allows for consistent estimations of the spending cycles in an institutionally fixed framework.

Our main findings can be summarised as follows: 1) We find sizable and statistically significant unconditional pre-election effects for legislative elections that are significant at the 5 percent level. Total expenditures are increased between 1.3-1.8 percent in the year before the legislative election takes place. 2) The budget cycle effects for the legislative branch are robust to the inclusion of election variables for the executive branch. 3) We find, on average, no unconditional (pre-)election PBC for executive branch elections. 4) The findings also hold for the interaction effects when we condition on whether the incumbent mayor runs for re-election. However, if we look at differences for the incumbent effect at times of elections, 5) we highlight increased spending in pre-election years if the incumbent seeks re-election at the 5 percent level. Finally, 6) we find insightful differences for overlapping cycles conditional on the incumbent's decision to seek re-election. Municipal expenditures increase in joint pre-election and election years if the mayor runs for re-election and decline in joint post-election years if she did not. Those effects are statistically significant at the 5 percent level.

Our results support the following conclusions: First, joint legislative and executive branch elections seem to matter for the formation of PBCs. Separating local elections thus can reduce politically motivated distortions in expenditures before elections. Second, our findings for increased spending before executive elections when the incumbent mayor seeks re-election may justify age and term limits. In BAY and BW, we have (in)direct age limits but no term limit restrictions. Abolishing the age limits likely would add to the number of incumbent candidates seeking re-election, while introducing term limits would work in the opposite direction. Nonetheless, we would refrain from drawing explicit inferences from our results. On the one hand, strong age and term limit rules could be viewed as restraining overspending before joint executive and legislative branch elections. However, the chief executive's incentive to manipulate the one election in which she could be re-elected (if we assume a two-term limit) could even become stronger (see, for instance, Klein and Sakurai, 2015, in the context of subnational elections in Brazil). Thus, it is not obvious whether the introduction of term limits would weaken or strengthen the overall effect of strategic budgetary 
manipulation in the long run and is, therefore, a question open for further research. 


\section{References}

Ade, F., Freier, R., 2013. Divided government versus incumbency externality effect - quasiexperimental evidence on multiple voting decisions. European Economic Review 64, 1-20.

Aidt, T. S., Mooney, G., 2014. Voting suffrage and the political budget cycle: Evidence from the London Metropolitan Boroughs 1902-1937. Journal of Public Economics 122, 53-71.

Aidt, T. S., Veiga, F. J., Veiga, L. G., 2011. Election results and opportunistic policies: a new test of the rational political business cycle model. Public Choice 148 (1-2), 21-44.

Akhmedov, A., Zhuravskaya, E., 2004. Opportunistic political cycles: test in a young democracy setting. The Quarterly Journal of Economics 119 (4), 1301-1338.

Alesina, A., 1987. Macroeconomic policy in a two-party system as a repeated game. The Quarterly Journal of Economics 102 (3), 651-678.

Alesina, A., 1988a. Credibility and political convergence in a two-party system with rational voters. American Economic Review 78 (4), 796-805.

Alesina, A., 1988b. Macroeconomics and politics. National Bureau of Economic Research Macroeconomics Annual 3, 13-61.

Alesina, A., Cohen, G. D., Roubini, N., 1992. Macroeconomic policies and elections in OECD democracies. Economics and Politics 4 (1), 1-30.

Alesina, A., Passalacqua, A., 2016. The political economy of government debt. In: Taylor, J. B., Uhlig, H. (Eds.), Handbook of Macroeconomics. Vol. 2B. North-Holland, Amsterdam, Ch. 33, pp. 2599-2651.

Alesina, A., Roubini, N., Cohen, G. D., 1997. Political cycles and the macroeconomy. MIT Press.

Alt, J. E., Rose, S. S., 2009. Context-conditional political cycles. In: Boix, C., Stokes, S. C. (Eds.), The Oxford Handbook of Comparative Politics. Oxford University Press, pp. 1-18.

Angrist, J. D., Pischke, J.-S., 2009. Mostly harmless econometris: an empiricist's companion. Princeton University Press.

Asatryan, Z., Baskaran, T., Grigoriadis, T., Heinemann, F., 2017. Direct democracy and local public finances under cooperative federalism. The Scandinavian Journal of Economics 119 (3), 801-820. 
Baleiras, R. N., da Silva Costa, J., 2004. To be or not to be in office again: an empirical test of a local political business cycle rational. European Journal of Political Economy 20 (3), 655-671.

Baskaran, T., 2012. Soft budget constraints and strategic interactions in subnational borrowing: evidence from the German states, 1975-2005. Journal of Urban Economics 71 (1), $114-127$.

Baskaran, T., Brender, A., Blesse, S., Reingewertz, Y., 2016. Revenue decentralisation, central oversight and the budget cycle: Evidence from Israel. European Journal of Political Economy 42, 1-16.

Benito, B., Bastida, F., Vicente, C., 2013. Creating room for manoeuvre: a strategy to generate political budget cycles under fiscal rules. Kyklos 66 (4), 467-496.

Binet, M.-E., Pentecôte, J.-S., 2004. Tax degression and the political budget cycle in French municipalities. Applied Economics Letters 11 (14), 905-908.

Blais, A., Nadeau, R., 1992. The electoral budget cycle. Public Choice 74 (4), 389-403.

Brender, A., Drazen, A., 2005. Political budget cycles in new versus established economies. Journal of Monetary Economics 52 (7), 1271-1295.

Chortareas, G., Logothetis, V., Papandreou, A. A., 2016. Political budget cycles and reelection prospects in Greece's municipalities. European Journal of Political Economy 43, $1-13$.

Cioffi, M., Messina, G., Tommasino, P., 2012. Parties, institutions and political budget cycles at municipal level: evidence from Italy. Banca d'Italia Working Paper 885.

Drazen, A., Eslava, M., 2010. Electoral manipulation via expenditure composition: theory and evidence. Journal of Development Economics 92 (1), 39-52.

Dubois, E., 2016. Political business cycles 40 years after Nordhaus. Public Choice 116 (1-2), 235-259.

Englmaier, F., Stowasser, T., 2013. Electoral cycles in savings bank lending. CESifo Working Paper No. 4402.

Federal Statistical Office, 2011. Finanzen und Steuern: Rechnungsergebnisse der öffentlichen Haushalte. Federal Statistical Office, Wiesbaden.

Foremny, D., Riedel, N., 2014. Business taxes and the electoral cycle. Journal of Public Economics 115, 48-61. 
Foucault, M., Madies, T., Paty, S., 2008. Public spending interactions and local politics. Empirical evidence from French municipalities. Public Choice 137, 57-80.

Freier, R., 2015. The mayor's advantage: causal evidence on incumbency effects in German mayoral elections. European Journal of Political Economy 40, 16-30.

Freier, R., Odendahl, C., 2015. Do parties matter? Estimating the effect of political power in multi-party systems. European Economic Review 80, 310-328.

Furdas, M., Homolkova, K., Kis-Katos, K., 2015. Local political budget cycles in a federation: Evidence from West German cities. IZA Discussion Paper No. 8798.

Galli, E., Rossi, S. P., 2002. Political budget cycle: The case of West German Länder. Public Choice 110 (3-4), 283-303.

Garmann, S., 2015. Elected or appointed? How the nomination scheme of the city manager influences the effects of government fragmentation. Journal of Urban Economics 86, 26-42.

Garmann, S., 2017a. Political budget cycles and divided government. Regional Studies forthcoming, 1-13.

Garmann, S., 2017b. Political budget cycles and fiscally conservative voters. Economics Letters $155,72-75$.

German Federal Pension Fund, 2014. Rentenversicherung in Zeitreihen: Ausgabe 2014. Deutsche Rentenversicherung.

Golden, D. G., Poterba, J. M., 1980. The price of popularity: the political business cycle reexamined. American Journal of Political Science 24 (4), 696-714.

Heinemann, F., Janeba, E., Moessinger, M.-D., Schröder, C., 2015. Who likes to fend for oneself? Revenue autonomy preferences of subnational politicians in Germany. Publius: The Journal of Federalism 45, 653-685.

Hessami, Z., 2018. Accountability and incentives of appointed and elected public officials. Review of Economics and Statistics 100 (1), 51-64.

Hibbs, D. A. J., 1977. Political parties and macroeconomic policy. American Political Science Review 71 (4), 1467-1487.

Keech, W. R., Pak, K., 1989. Electoral cycles and budgetary growth in veterans' benefit programs. American Journal of Political Science 33 (4), 901-911.

Kessing, S. G., 2010. Federalism and accountability with distorted election choices. Journal of Urban Economics 67 (2), 239-247. 
Khemani, S., 2004. Political cycles in a developing economy: effect of elections in the Indian states. Journal of Development Economics 73, 125-154.

Klein, F. A., Sakurai, S. N., 2015. Term limits and political budget cycles at the local level: evidence from a young democracy. European Journal of Political Economy 37, 21-36.

Klomp, J., De Haan, J., 2013. Do political budget cycles really exist? Applied Economics $45,329-341$.

Kluge, J., Markwardt, G., Thater, C., 2015. Self-preserving leviathans: evidence from regional-level data. CESifo Working Paper No. 5177.

Kneebone, R. D., Mckenzie, K. J., 2001. Electoral and partisan cycles in fiscal policy: an examination of Canadian provinces. International Tax and Public Finance 8 (5-6), 753774.

Köppl-Turyna, M., 2016. Opportunistic politicians and fiscal outcomes: the curious case of vorarlberg. Public Choice 168 (3-4), 177-216.

Lächler, U., 1978. The political business cycle: a complementary study. The Review of Economic Studies 45 (2), 369-375.

Mechtel, M., Potrafke, N., 2013. Electoral cycles in active labour market policies. Public Choice 156 (1-2), 181-194.

Nordhaus, W. D., 1975. The political business cycle. The Review of Economic Studies 42, 169-190.

Persson, T., Tabellini, G., 2000. Political economics - explaining economic policy. The MIT Press.

Philips, A. Q., 2016. Seeing the forest through the trees: A meta-analysis of political budget cycles. Public Choice 168 (3-4), 313-341.

Potrafke, N., 2012. Political cycles and economic performance in OECD countries: empirical evidence from 1951-2006. Public Choice 150, 155-179.

Rogoff, K., 1990. Equilibrium political budget cycles. American Economic Review 80(1), $21-36$.

Rogoff, K., Sibert, A., 1988. Elections and macroeconomic policy cycles. Review of Economic Studies 55(1), 1-16.

Rose, S. S., 2006. Do fiscal rules dampen the political business cycle. Public Choice 128 (3-4), $407-431$. 
Rosenberg, J., 1992. Rationality and the political business cycle: the case of local government. Public Choice 73 (1), 71-81.

Sakurai, S. N., Menezes-Filho, N., 2011. Opportunistic and partisan election cycles in Brazil: new evidence at the municipal level. Public Choice 148 (1-2).

Schneider, C. J., 2010. Fighting with one hand tied behind the back: political budget cycles in the West German states. Public Choice 142, 125-150.

Schuknecht, L., 1999. Fiscal policy cycles and the exchange rate regime in developing countries. European Journal of Political Economy 15 (3), 569-580.

Seitz, H., 2000. Fiscal policy, deficits and politics of subnational governments: the case of German Länder. Public Choice 102 (3-4), 183-218.

Shi, M., Svensson, J., 2006. Political budget cycles: Do they differ across countries and why? Journal of Public Economics 90, 1367-1389.

Sjahrir, B. S., Kis-Katos, K., Schulze, G. G., 2013. Political budget cycles in Indonesia at the district level. Economics Letters 120, 342-345.

Solé-Ollé, A., Viladecans-Marsal, E., 2013. Do political parties matter for local land use policies? Journal of Urban Economics 78, 42-56.

Strate, J., Wolman, H., Melchior, A., 1993. Are there election-driven tax- and expenditure cycles for urban governments? Urban Affairs Quarterly 28 (3), 462-479.

Veiga, L. G., Veiga, F. J., 2007. Political business cycle at the municipal level. Public Choice 131 (1-2), 45-64.

Wooldridge, J. M., 2010. Econometric analysis of cross section and panel data. MIT Press.

\section{A. Appendix}




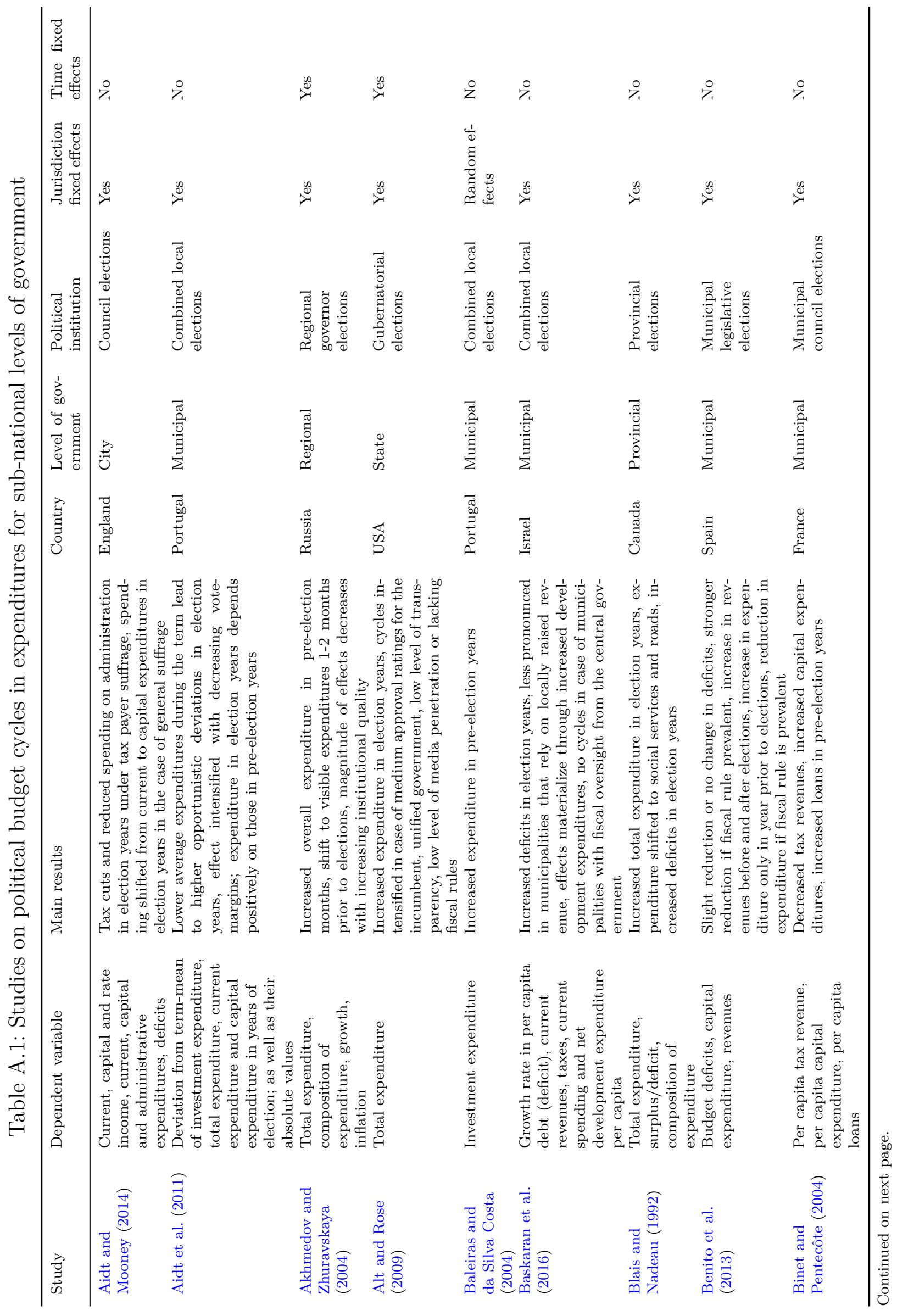




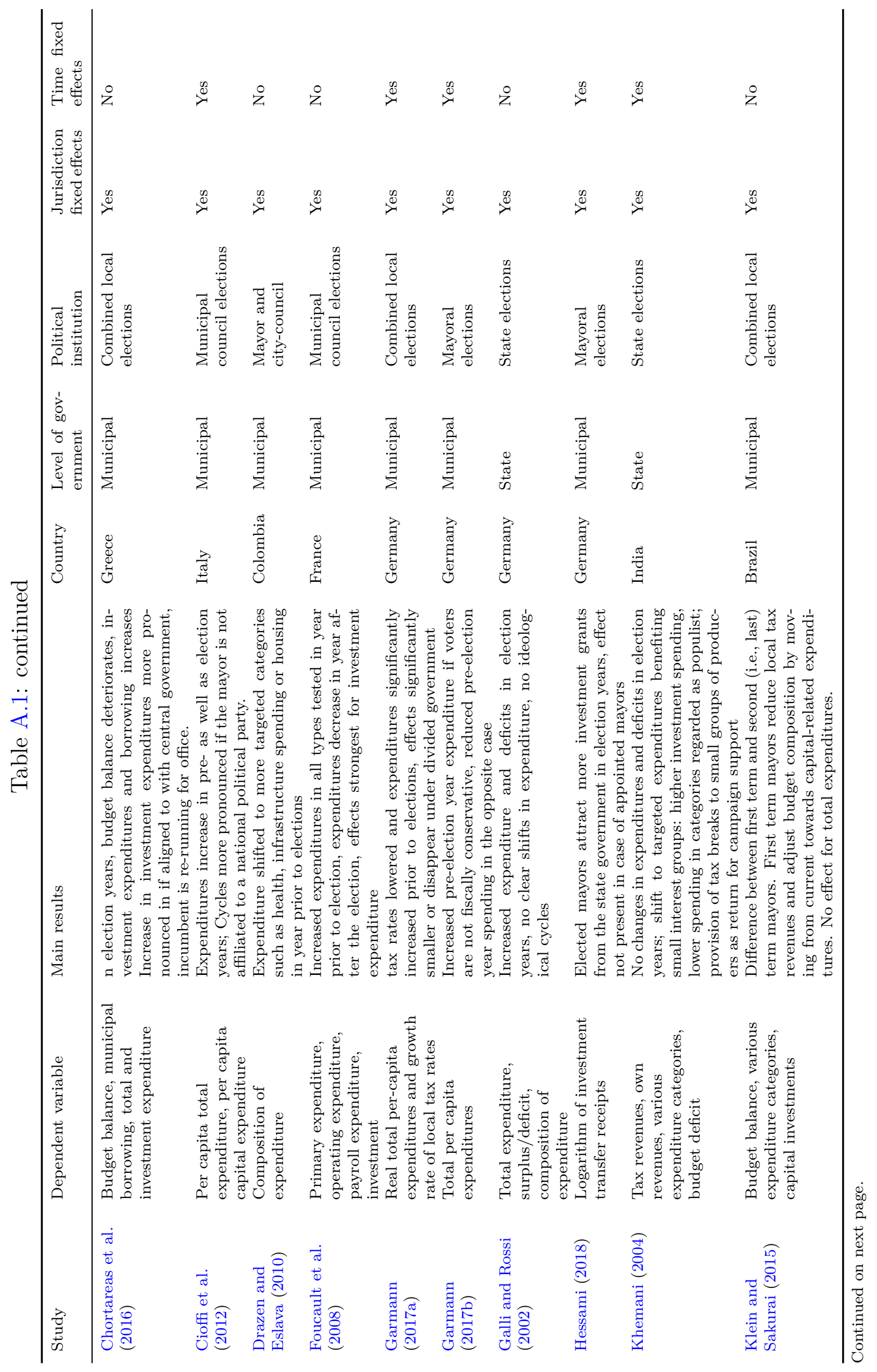




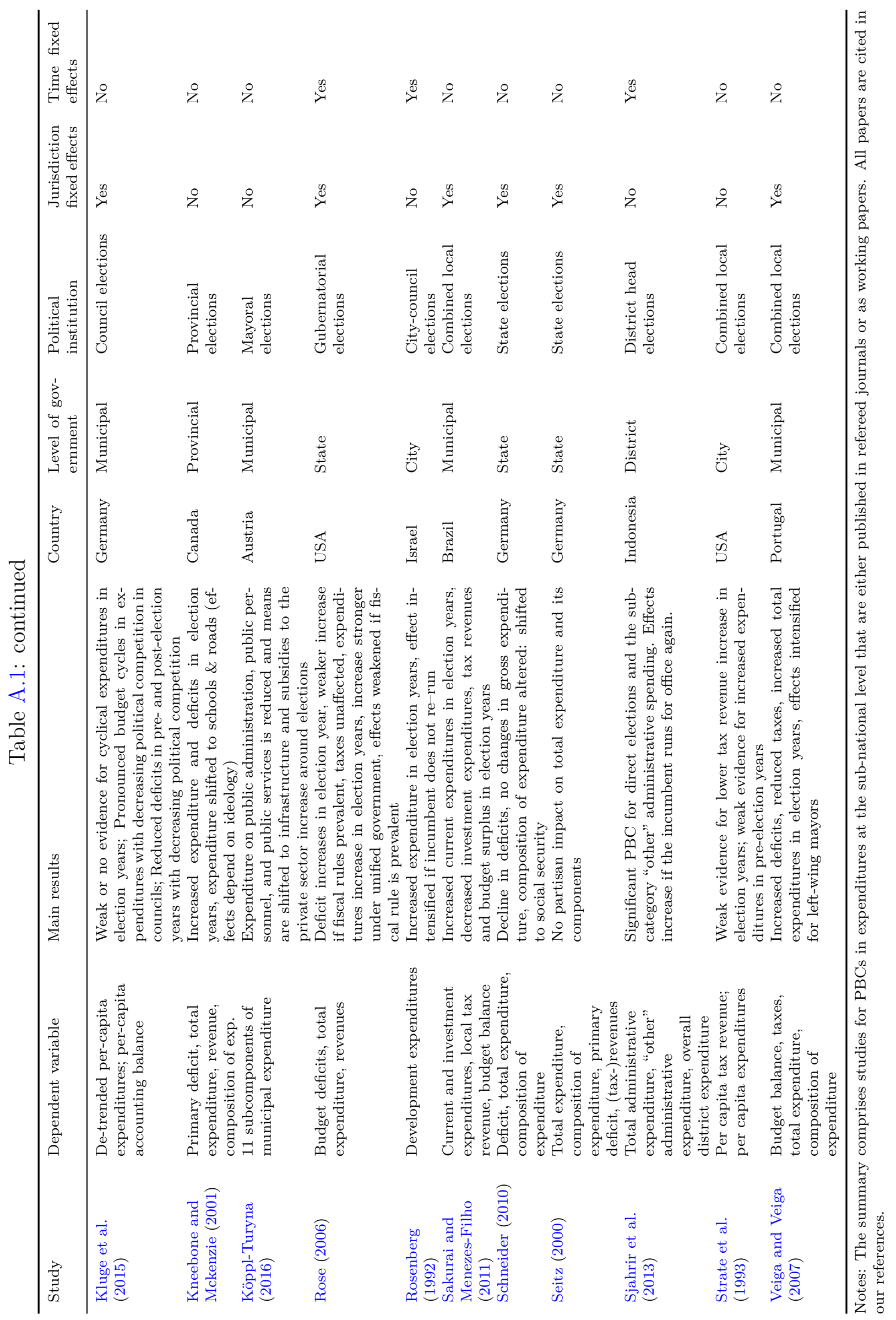




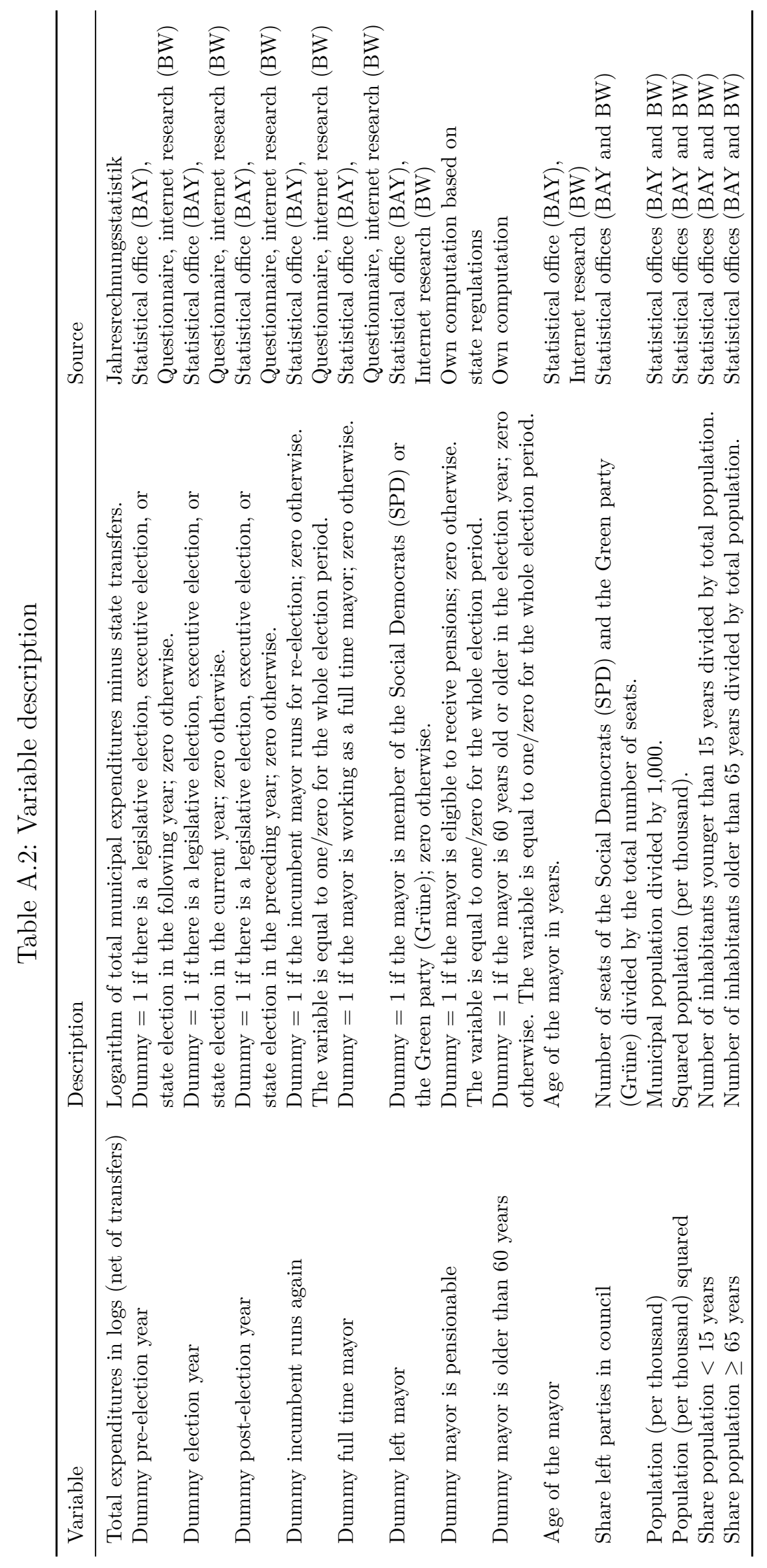


Table A.3: Sample selection comparison for BW

\begin{tabular}{lccccc}
\hline & \multicolumn{2}{c}{ Full Sample } & & \multicolumn{2}{c}{ Estimation Sample } \\
\cline { 2 - 3 } \cline { 6 - 6 } & No/Mean & S.D. & & No/Mean & S.D. \\
\hline Number of municipalities & 1101 & - & & 968 & - \\
Municipal-year observations & 16515 & - & & 10531 & - \\
Log total exp. (net of transfers) & 15.964 & 1.182 & & 16.116 & 1.143 \\
Population (per thousands) & 9.481 & 25.54 & & 10.800 & 28.19 \\
Population share $<15$ & 0.182 & 0.024 & & 0.180 & 0.024 \\
Population share $>65$ & 0.151 & 0.029 & & 0.155 & 0.029 \\
\hline
\end{tabular}


Table A.4: PBCs in public expenditure (fixed effects OLS regression)

\begin{tabular}{|c|c|c|c|c|c|c|}
\hline & $\begin{array}{l}\text { Depen } \\
(1)\end{array}$ & $\begin{array}{l}\text { ent variable: } \\
\quad(2)\end{array}$ & $\begin{array}{l}\text { total exper } \\
\text { (3) }\end{array}$ & $\begin{array}{l}\text { litures in } 1 \\
\quad(4)\end{array}$ & s (net of $\mathrm{tr}$ & $\begin{array}{l}\text { sfers) } \\
\quad(6)\end{array}$ \\
\hline $\begin{array}{l}\text { Legislative elections } \\
\text { Pre-election year }\end{array}$ & $\begin{array}{c}0.015^{* *} \\
{[2.398]}\end{array}$ & & $\begin{array}{c}0.013^{* *} \\
{[2.090]}\end{array}$ & $\begin{array}{c}0.014^{* *} \\
{[2.141]}\end{array}$ & $\begin{array}{c}0.014^{* *} \\
{[2.246]}\end{array}$ & $\begin{array}{l}0.018^{*} \\
{[1.691]}\end{array}$ \\
\hline Election year & $\begin{array}{c}0.002 \\
{[0.257]}\end{array}$ & & $\begin{array}{l}-0.002 \\
{[-0.296]}\end{array}$ & $\begin{array}{c}0.000 \\
{[0.037]}\end{array}$ & $\begin{array}{l}-0.002 \\
{[-0.251]}\end{array}$ & $\begin{array}{l}-0.003 \\
{[-0.268]}\end{array}$ \\
\hline Post-election year & $\begin{array}{c}0.005 \\
{[0.996]}\end{array}$ & & $\begin{array}{c}0.000 \\
{[0.011]}\end{array}$ & $\begin{array}{l}-0.004 \\
{[-0.547]}\end{array}$ & $\begin{array}{c}0.000 \\
{[0.088]}\end{array}$ & $\begin{array}{l}-0.007 \\
{[-0.672]}\end{array}$ \\
\hline $\begin{array}{l}\text { Executive elections } \\
\text { Pre-election year }\end{array}$ & & $\begin{array}{c}0.003 \\
{[0.876]}\end{array}$ & $\begin{array}{c}0.001 \\
{[0.193]}\end{array}$ & $\begin{array}{c}0.002 \\
{[0.462]}\end{array}$ & $\begin{array}{c}-0.018^{* * *} \\
{[-2.590]}\end{array}$ & $\begin{array}{l}-0.003 \\
{[-0.310]}\end{array}$ \\
\hline Election year & & $\begin{array}{l}0.006 \\
{[1.442]}\end{array}$ & $\begin{array}{c}0.006 \\
{[1.511]}\end{array}$ & $\begin{array}{c}0.007 \\
{[1.310]}\end{array}$ & $\begin{array}{l}-0.007 \\
{[-0.865]}\end{array}$ & $\begin{array}{c}0.009 \\
{[0.804]}\end{array}$ \\
\hline Post-election year & & $\begin{array}{c}0.009^{* * *} \\
{[2.612]}\end{array}$ & $\begin{array}{c}0.009^{* *} \\
{[2.420]}\end{array}$ & $\begin{array}{l}0.006 \\
{[1.251]}\end{array}$ & $\begin{array}{l}-0.005 \\
{[-0.626]}\end{array}$ & $\begin{array}{l}-0.009 \\
{[-0.775]}\end{array}$ \\
\hline $\begin{array}{c}\text { Executive elections } \times \text { legislative } \\
\text { Joint pre-election year }\end{array}$ & & & & $\begin{array}{l}-0.005 \\
{[-0.518]}\end{array}$ & & $\begin{array}{l}-0.023 \\
{[-1.344]}\end{array}$ \\
\hline Joint election year & & & & $\begin{array}{l}-0.004 \\
{[-0.452]}\end{array}$ & & $\begin{array}{l}-0.022 \\
{[-1.370]}\end{array}$ \\
\hline Joint post-election year & & & & $\begin{array}{c}0.008 \\
{[0.865]}\end{array}$ & & $\begin{array}{c}0.012 \\
{[0.775]}\end{array}$ \\
\hline $\begin{array}{l}\text { Executive elections } \times \text { incumbent runs again } \\
\text { Pre-election vear }\end{array}$ & & & & & $\begin{array}{c}0.024^{* * *} \\
{[3.209]}\end{array}$ & $\begin{array}{c}0.007 \\
{[0.627]}\end{array}$ \\
\hline Election year & & & & & $\begin{array}{l}0.017^{*} \\
{[1.763]}\end{array}$ & $\begin{array}{l}-0.005 \\
{[-0.344]}\end{array}$ \\
\hline Post-election year & & & & & $\begin{array}{l}0.019^{*} \\
{[1.940]}\end{array}$ & $\begin{array}{c}0.020 \\
{[1.505]}\end{array}$ \\
\hline $\begin{array}{l}\text { Legislative elections } \times \text { incumber } \\
\text { Pre-election year }\end{array}$ & & & & & & $\begin{array}{l}-0.003 \\
{[-0.263]}\end{array}$ \\
\hline Election year & & & & & & $\begin{array}{c}0.005 \\
{[0.493]}\end{array}$ \\
\hline Post-election year & & & & & & $\begin{array}{c}0.005 \\
{[0.508]}\end{array}$ \\
\hline $\begin{array}{l}\text { Joint elections } \times \text { incumbent rur } \\
\text { Pre-election years }\end{array}$ & & & & & & $\begin{array}{c}0.024 \\
{[1.301]}\end{array}$ \\
\hline Election years & & & & & & $\begin{array}{c}0.025 \\
{[1.410]}\end{array}$ \\
\hline Post-election years & & & & & & $\begin{array}{l}-0.006 \\
{[-0.388]}\end{array}$ \\
\hline Incumbent runs again dummy & $\begin{array}{c}0.013^{* * *} \\
{[2.940]}\end{array}$ & $\begin{array}{c}0.013^{* * *} \\
{[3.053]}\end{array}$ & $\begin{array}{c}0.013^{* * *} \\
{[3.050]}\end{array}$ & $\begin{array}{c}0.013^{* * *} \\
{[3.043]}\end{array}$ & $\begin{array}{c}0.004 \\
{[0.718]}\end{array}$ & $\begin{array}{c}0.004 \\
{[0.631]}\end{array}$ \\
\hline Control variables & $\checkmark$ & $\checkmark$ & $\checkmark$ & $\checkmark$ & $\checkmark$ & $\checkmark$ \\
\hline Observations & 39554 & 39554 & 39554 & 39554 & 39554 & 39554 \\
\hline$R^{2}$ & 0.077 & 0.077 & 0.077 & 0.077 & 0.077 & 0.077 \\
\hline Cluster & 3017 & 3017 & 3017 & 3017 & 3017 & 3017 \\
\hline$A I C$ & -13148.6 & -13148.7 & -13147.1 & -13142 & -13156.2 & -13144.6 \\
\hline$S B I C$ & -12882.5 & -12882.5 & -12855.2 & -12824.4 & -12838.5 & -12749.7 \\
\hline
\end{tabular}


Table A.5: PBCs in public expenditure: Control variables for Table A.4

\begin{tabular}{|c|c|c|c|c|c|c|}
\hline & \multicolumn{6}{|c|}{ Dependent variable: total expenditures in logs (net of transfers) } \\
\hline Share left parties in council & $\begin{array}{c}0.024 \\
{[0.571]}\end{array}$ & $\begin{array}{c}0.024 \\
{[0.580]}\end{array}$ & $\begin{array}{c}0.023 \\
{[0.554]}\end{array}$ & $\begin{array}{c}0.023 \\
{[0.554]}\end{array}$ & $\begin{array}{c}0.023 \\
{[0.555]}\end{array}$ & $\begin{array}{c}0.023 \\
{[0.552]}\end{array}$ \\
\hline Dummy left mayor & $\begin{array}{l}-0.008 \\
{[-0.774]}\end{array}$ & $\begin{array}{l}-0.008 \\
{[-0.771]}\end{array}$ & $\begin{array}{l}-0.008 \\
{[-0.766]}\end{array}$ & $\begin{array}{l}-0.008 \\
{[-0.765]}\end{array}$ & $\begin{array}{l}-0.008 \\
{[-0.762]}\end{array}$ & $\begin{array}{l}-0.008 \\
{[-0.754]}\end{array}$ \\
\hline Dummy full time mayor & $\begin{array}{c}0.012 \\
{[0.815]}\end{array}$ & $\begin{array}{c}0.012 \\
{[0.797]}\end{array}$ & $\begin{array}{c}0.012 \\
{[0.807]}\end{array}$ & $\begin{array}{c}0.012 \\
{[0.805]}\end{array}$ & $\begin{array}{c}0.012 \\
{[0.809]}\end{array}$ & $\begin{array}{c}0.012 \\
{[0.800]}\end{array}$ \\
\hline Age of the mayor & $\begin{array}{c}0.000 \\
{[0.700]}\end{array}$ & $\begin{array}{c}0.000 \\
{[0.863]}\end{array}$ & $\begin{array}{c}0.000 \\
{[0.836]}\end{array}$ & $\begin{array}{c}0.000 \\
{[0.840]}\end{array}$ & $\begin{array}{c}0.000 \\
{[0.133]}\end{array}$ & $\begin{array}{c}0.000 \\
{[0.140]}\end{array}$ \\
\hline $\begin{array}{l}\text { State elections } \\
\quad \text { Pre-election year }\end{array}$ & $\begin{array}{l}-0.003 \\
{[-0.527]}\end{array}$ & $\begin{array}{l}-0.004 \\
{[-1.066]}\end{array}$ & $\begin{array}{l}-0.002 \\
{[-0.284]}\end{array}$ & $\begin{array}{c}0.001 \\
{[0.091]}\end{array}$ & $\begin{array}{l}-0.002 \\
{[-0.341]}\end{array}$ & $\begin{array}{c}0.000 \\
{[0.048]}\end{array}$ \\
\hline Election year & $\begin{array}{c}0.011^{* *} \\
{[2.088]}\end{array}$ & $\begin{array}{c}0.003 \\
{[1.075]}\end{array}$ & $\begin{array}{l}0.010^{*} \\
{[1.799]}\end{array}$ & $\begin{array}{l}0.009^{*} \\
{[1.746]}\end{array}$ & $\begin{array}{l}0.010^{*} \\
{[1.856]}\end{array}$ & $\begin{array}{l}0.010^{*} \\
{[1.854]}\end{array}$ \\
\hline Post-election year & $\begin{array}{c}0.021^{* * *} \\
{[4.028]}\end{array}$ & $\begin{array}{c}0.024^{* * *} \\
{[7.054]}\end{array}$ & $\begin{array}{c}0.021^{* * *} \\
{[4.025]}\end{array}$ & $\begin{array}{c}0.023^{* * *} \\
{[4.324]}\end{array}$ & $\begin{array}{c}0.021^{* * *} \\
{[3.952]}\end{array}$ & $\begin{array}{c}0.023^{* * *} \\
{[4.307]}\end{array}$ \\
\hline Population & $\begin{array}{c}0.018^{* * *} \\
{[3.377]}\end{array}$ & $\begin{array}{c}0.018^{* * *} \\
{[3.418]}\end{array}$ & $\begin{array}{c}0.018^{* * *} \\
{[3.402]}\end{array}$ & $\begin{array}{c}0.018^{* * *} \\
{[3.409]}\end{array}$ & $\begin{array}{c}0.018^{* * *} \\
{[3.404]}\end{array}$ & $\begin{array}{c}0.018^{* * *} \\
{[3.407]}\end{array}$ \\
\hline Population squared & $\begin{array}{c}-0.007^{* * *} \\
{[-2.993]}\end{array}$ & $\begin{array}{c}-0.007^{* * *} \\
{[-3.037]}\end{array}$ & $\begin{array}{c}-0.007^{* * *} \\
{[-3.029]}\end{array}$ & $\begin{array}{c}-0.007^{* * *} \\
{[-3.037]}\end{array}$ & $\begin{array}{c}-0.007^{* * *} \\
{[-3.014]}\end{array}$ & $\begin{array}{c}-0.007^{* * *} \\
{[-3.029]}\end{array}$ \\
\hline Share population $<15$ years & $\begin{array}{c}0.288 \\
{[1.156]}\end{array}$ & $\begin{array}{c}0.293 \\
{[1.177]}\end{array}$ & $\begin{array}{c}0.288 \\
{[1.155]}\end{array}$ & $\begin{array}{c}0.288 \\
{[1.158]}\end{array}$ & $\begin{array}{c}0.290 \\
{[1.164]}\end{array}$ & $\begin{array}{c}0.292 \\
{[1.171]}\end{array}$ \\
\hline Share population $>65$ years & $\begin{array}{c}0.131 \\
{[0.737]}\end{array}$ & $\begin{array}{c}0.181 \\
{[1.096]}\end{array}$ & $\begin{array}{c}0.142 \\
{[0.792]}\end{array}$ & $\begin{array}{c}0.151 \\
{[0.831]}\end{array}$ & $\begin{array}{c}0.151 \\
{[0.842]}\end{array}$ & $\begin{array}{c}0.160 \\
{[0.878]}\end{array}$ \\
\hline Trend BAY & $\begin{array}{c}0.029^{* * *} \\
{[14.338]}\end{array}$ & $\begin{array}{c}0.020^{* * *} \\
{[9.572]}\end{array}$ & $\begin{array}{c}0.030^{* * *} \\
{[14.364]}\end{array}$ & $\begin{array}{c}0.030^{* * *} \\
{[14.358]}\end{array}$ & $\begin{array}{c}0.030^{* * *} \\
{[14.421]}\end{array}$ & $\begin{array}{c}0.030^{* * *} \\
{[14.407]}\end{array}$ \\
\hline Trend BAY squared & $\begin{array}{c}-0.001^{* * *} \\
{[-5.980]}\end{array}$ & $\begin{array}{c}-0.000^{* * *} \\
{[-2.977]}\end{array}$ & $\begin{array}{c}-0.001^{* * *} \\
{[-6.018]}\end{array}$ & $\begin{array}{c}-0.001 * * * \\
{[-6.015]}\end{array}$ & $\begin{array}{c}-0.001^{* * *} \\
{[-6.079]}\end{array}$ & $\begin{array}{c}-0.001^{* * *} \\
{[-6.077]}\end{array}$ \\
\hline Trend BW & $\begin{array}{c}0.036^{* * *} \\
{[13.353]}\end{array}$ & $\begin{array}{c}0.025^{* * *} \\
{[9.853]}\end{array}$ & $\begin{array}{c}0.036^{* * *} \\
{[13.396]}\end{array}$ & $\begin{array}{c}0.036^{* * *} \\
{[13.344]}\end{array}$ & $\begin{array}{c}0.036^{* * *} \\
{[13.352]}\end{array}$ & $\begin{array}{c}0.036^{* * *} \\
{[13.345]}\end{array}$ \\
\hline Trend BW squared & $\begin{array}{c}-0.001^{* * *} \\
{[-5.836]}\end{array}$ & $\begin{array}{l}-0.000^{*} \\
{[-1.762]}\end{array}$ & $\begin{array}{c}-0.001^{* * *} \\
{[-5.912]}\end{array}$ & $\begin{array}{c}-0.001^{* * *} \\
{[-5.888]}\end{array}$ & $\begin{array}{c}-0.001^{* * *} \\
{[-5.923]}\end{array}$ & $\begin{array}{c}-0.001^{* * *} \\
{[-5.923]}\end{array}$ \\
\hline Constant & $\begin{array}{c}15.153^{* * *} \\
{[226.984]}\end{array}$ & $\begin{array}{c}15.141^{* * *} \\
{[229.019]}\end{array}$ & $\begin{array}{c}15.147^{* * *} \\
{[225.610]}\end{array}$ & $\begin{array}{c}15.146^{* * *} \\
{[224.519]}\end{array}$ & $\begin{array}{c}15.165^{* * *} \\
{[219.643]}\end{array}$ & $\begin{array}{c}15.163^{* * *} \\
{[218.392]}\end{array}$ \\
\hline $\begin{array}{l}\text { Observations } \\
R^{2} \\
\text { Cluster }\end{array}$ & $\begin{array}{c}39554 \\
0.077 \\
3017\end{array}$ & $\begin{array}{l}39554 \\
0.077 \\
3017\end{array}$ & $\begin{array}{l}39554 \\
0.077 \\
3017\end{array}$ & $\begin{array}{c}39554 \\
0.077 \\
3017\end{array}$ & $\begin{array}{c}39554 \\
0.077 \\
3017\end{array}$ & $\begin{array}{c}39554 \\
0.077 \\
3017\end{array}$ \\
\hline
\end{tabular}

Notes: All specifications include municipality and time fixed effects. Robust t-values are shown in brackets. $* * *$, $(* *),(*)$ denotes significance at the 1-, (5-), (10-)\%-level. Error terms are clustered at the municipal level. 
Table A.6: PBCs in public expenditure: First stage regression of Table 2

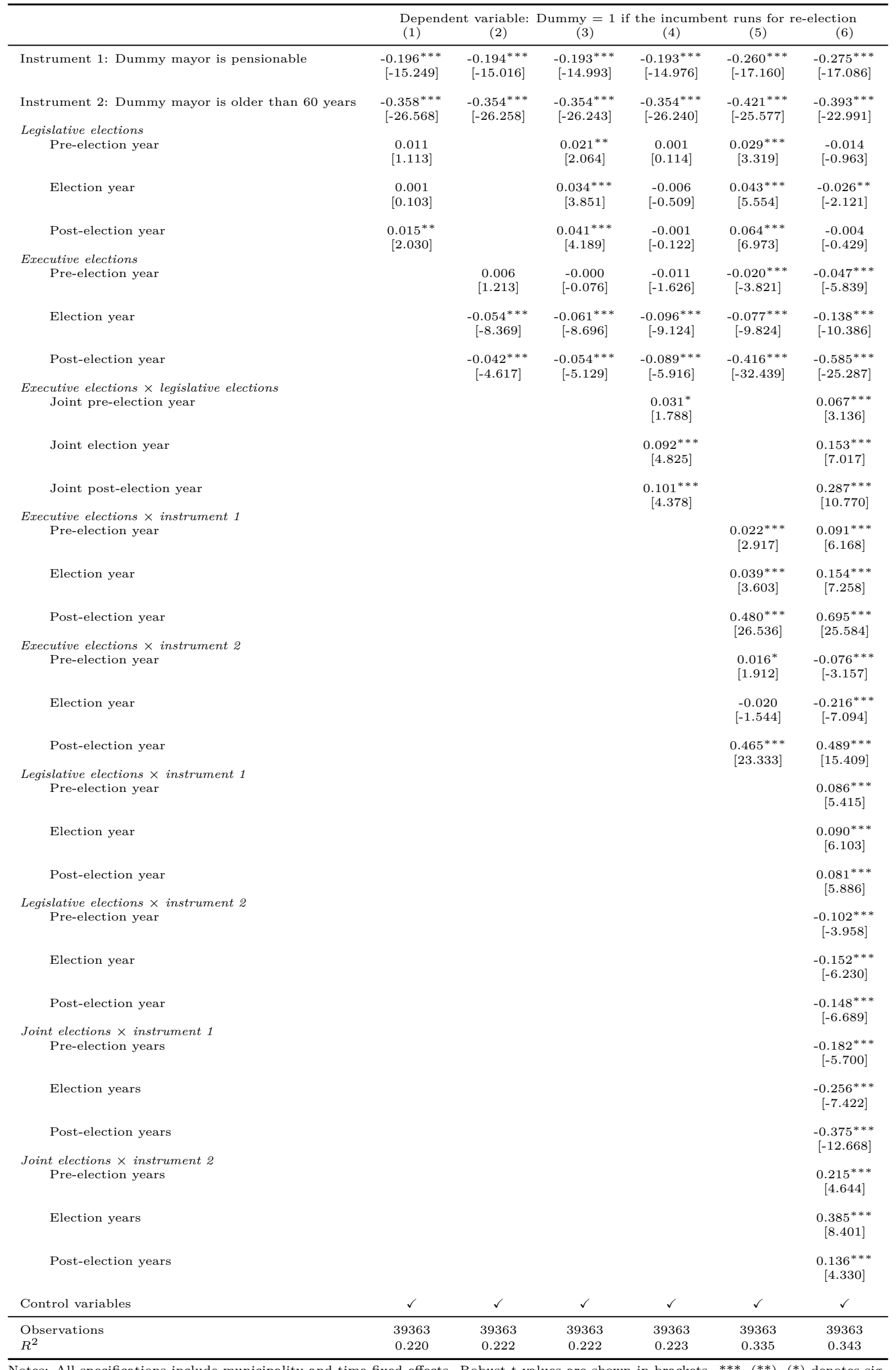

Notes: All specifications include municipality and time fixed effects. Robust t-values are shown in brackets. $*^{* *},(* *),(*)$ denotes significance at the 1-, (5-), (10-)\%-level. Error terms are clustered at the municipal level. The estimation includes the full set of additional 